Article

\title{
Application of Hydrologic Tools and Monitoring to Support Managed Aquifer Recharge Decision Making in the Upper San Pedro River, Arizona, USA
}

\author{
Laurel J. Lacher ${ }^{1, *}$, Dale S. Turner ${ }^{2}$, Bruce Gungle ${ }^{3}$, Brooke M. Bushman ${ }^{2}$ and \\ Holly E. Richter ${ }^{2}$
}

1 Lacher Hydrological Consulting, 821 S. Meyer Avenue, Tucson, AZ 85701, USA

2 The Nature Conservancy, 1510 E. Fort Lowell Road, Tucson, AZ 85719, USA; E-Mails: dturner@tnc.org (D.S.T.); bbushman@tnc.org (B.M.B.); hrichter@tnc.org (H.E.R.)

3 Arizona Water Science Center-U.S. Geological Survey, 520 N Park Avenue, Tucson, AZ 85719, USA; E-Mail: bgungle@usgs.gov

* Author to whom correspondence should be addressed; E-Mail: LLacher1@msn.com; Tel.: +1-520-548-2205; Fax: +1-866-401-0392.

External Editor: Sharon Megdal

Received: 17 June 2014; in revised form: 5 November 2014 / Accepted: 5 November 2014 / Published: 18 November 2014

\begin{abstract}
The San Pedro River originates in Sonora, Mexico, and flows north through Arizona, USA, to its confluence with the Gila River. The 92-km Upper San Pedro River is characterized by interrupted perennial flow, and serves as a vital wildlife corridor through this semiarid to arid region. Over the past century, groundwater pumping in this bi-national basin has depleted baseflows in the river. In 2007, the United States Geological Survey published the most recent groundwater model of the basin. This model served as the basis for predictive simulations, including maps of stream flow capture due to pumping and of stream flow restoration due to managed aquifer recharge. Simulation results show that ramping up near-stream recharge, as needed, to compensate for downward pumping-related stress on the water table, could sustain baseflows in the Upper San Pedro River at or above 2003 levels until the year 2100 with less than 4.7 million cubic meters per year (MCM/yr). Wet-dry mapping of the river over a period of 15 years developed a body of empirical evidence which, when combined with the simulation tools, provided powerful technical support to decision makers struggling to manage aquifer recharge to support baseflows in the river while also accommodating the economic needs of the basin.
\end{abstract}


Keywords: baseflow; recharge; wet-dry mapping; San Pedro River; near-stream; groundwater modeling; protect flows; enhance flows

\section{Introduction}

\subsection{Social Context}

Balancing the social and economic water needs of humans with those of the environment, frequently referred to as sustainable water management, presents a global challenge, especially in arid and semi-arid regions, such as the American Desert Southwest. Understanding that the concept of sustainable water management is subjective, particularly in areas where human groundwater extractions have long exceeded average annual natural recharge, this study focuses on the tension between human demands for groundwater and the groundwater needs of an exceedingly rare perennial river system within the same basin of Southeast Arizona.

We report here on a combination of hydrologic tools and monitoring that are supporting significant progress toward many measures of sustainability on the scale of decades at one important site. The case for developing a regional groundwater recharge network along the Upper San Pedro River is built upon a series of studies and reports funded by the Upper San Pedro Partnership (Partnership), and vetted by its Technical Committee over a period of approximately 15 years. The Partnership is a consortium of 23 agencies and organizations working together to meet the long-term water needs of the Sierra Vista Subwatershed by achieving sustainable yield of the regional aquifer to: (1) preserve the San Pedro Riparian National Conservation Area (SPRNCA); and (2) ensure the long-term viability of Fort Huachuca. The purpose of the Partnership is to coordinate and cooperate in the identification, prioritization and implementation of comprehensive policies and projects to assist in meeting water needs in the Sierra Vista Subwatershed of the Upper San Pedro River Basin. Richter and others [1] provide a more complete discussion of the purpose, methods, and vision encompassed by the Partnership. In addition, recent groundwater modeling efforts have focused stakeholders' collective understanding of the hydrologic system on actionable strategies. Together, this body of work helps identify potential spatial and temporal groundwater recharge targets for mitigating many of the negative environmental, regulatory and economic consequences that may result if groundwater inputs to the San Pedro River diminish as a result of pumping, as predicted by groundwater modeling. Using this information, three of the stakeholders including the U.S. Army Compatible Use Buffer (ACUB) Program, Cochise County, and The Nature Conservancy are collaborating to develop an aquifer protection and recharge network of sites in the San Pedro River basin to protect flows in the river from anticipated pumping-related depletions over the next 50 to 100 years. This interim solution is intended to allow time to develop other longer-term strategies for addressing issues of the accumulated groundwater deficit in the regional aquifer and climate change. Examples of such longer-term strategies could include gradual elimination of consumptive use of groundwater, limitations on new pumping, enhanced utilization of urban runoff, and importation of water from outside the basin. Most of these strategies are controversial and/or expensive, and would require significant political and legal efforts to secure physical water supplies. This approach — using the best available science to implement a relatively uncontroversial and 
legally available interim solution to preserve baseflows while more difficult long-term solutions are pursued - may serve as a model for other dry-land river basins.

\subsection{Study Area}

The San Pedro River flows north 279 kilometers $(\mathrm{km})$ from its headwaters in northeastern Sonora, Mexico, to its confluence with the Gila River in southeastern Arizona, U.S.A. This paper focuses on the 2460-km² Sierra Vista Subwatershed ("subwatershed") of the Upper San Pedro basin ("basin"), north of the United States-Mexico boundary (Figure 1). This subwatershed area includes about $47 \mathrm{~km}$ of the river, most of it within the San Pedro Riparian National Conservation Area (SPRNCA), designated by the United States Congress in 1988 to protect and enhance the riparian area and its aquatic resources [2].

Figure 1. Map of the Upper San Pedro Basin showing the extent of the USGS groundwater flow model [3] and the San Pedro Riparian National Conservation Area. The Sierra Vista subwatershed is the area north of the United States - Mexico boundary.

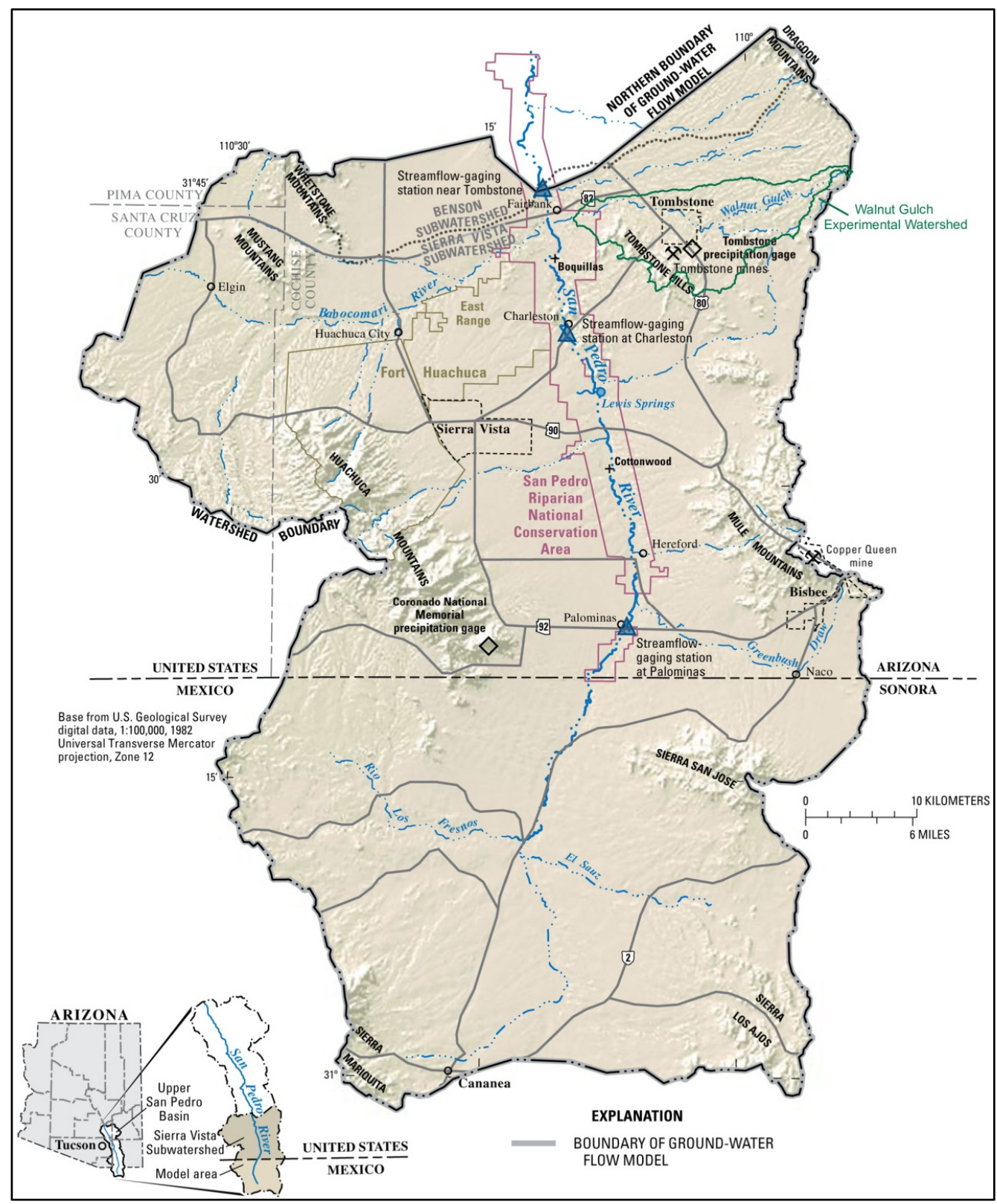


Elevations within the Sierra Vista subwatershed range from more than 2800 meters $(\mathrm{m})$ above mean sea level in the Huachuca Mountains on the western edge of the basin, to $1052 \mathrm{~m}$ at the Tombstone stream-flow gaging station at the north (downstream) end of the subwatershed. Precipitation across the topographically diverse basin ranges from 35 centimeters per year $(\mathrm{cm} / \mathrm{yr})$ near Tombstone in the central-north part of the subwatershed to about $76 \mathrm{~cm} /$ year in the highest parts of the Huachuca Mountains [4,5]. Like other areas in the desert southwest, precipitation in the study area is predictably bimodal with a summer monsoon season from July through mid-September accounting for about one half, and a winter wet season from December through March that accounts for another one third of the annual precipitation. Occasionally, tropical storms will trigger very large runoff events in October, but otherwise the fall months are typically dry. Stream flow is lowest in May and June, with peak monthly flows occurring during the summer monsoon season (Figure 2). Average monthly minimum flows range from about 1300 cubic meters per day (cu-m/d) at the Palominas stream-flow gaging station in the south (upstream) end of the subwatershed to $19,300 \mathrm{cu}-\mathrm{m} / \mathrm{d}$ at the Charleston station, and $8100 \mathrm{cu}-\mathrm{m} / \mathrm{d}$ at the Tombstone station on the north (downstream) end of the study area (Figure 2). Snow melt in the Huachuca Mountains often supports flow in mountain springs and intermittent streams in the spring months of March and April.

Figure 2. Mean monthly stream flow for the three long-term monitoring sites (shown in Figure 1) on the Upper San Pedro River in the Sierra Vista subwatershed for the period of record at each site. The y-axis is plotted on a log scale to highlight the minimum flows in May and June.

Mean Monthly Flow for Three San Pedro River Sites

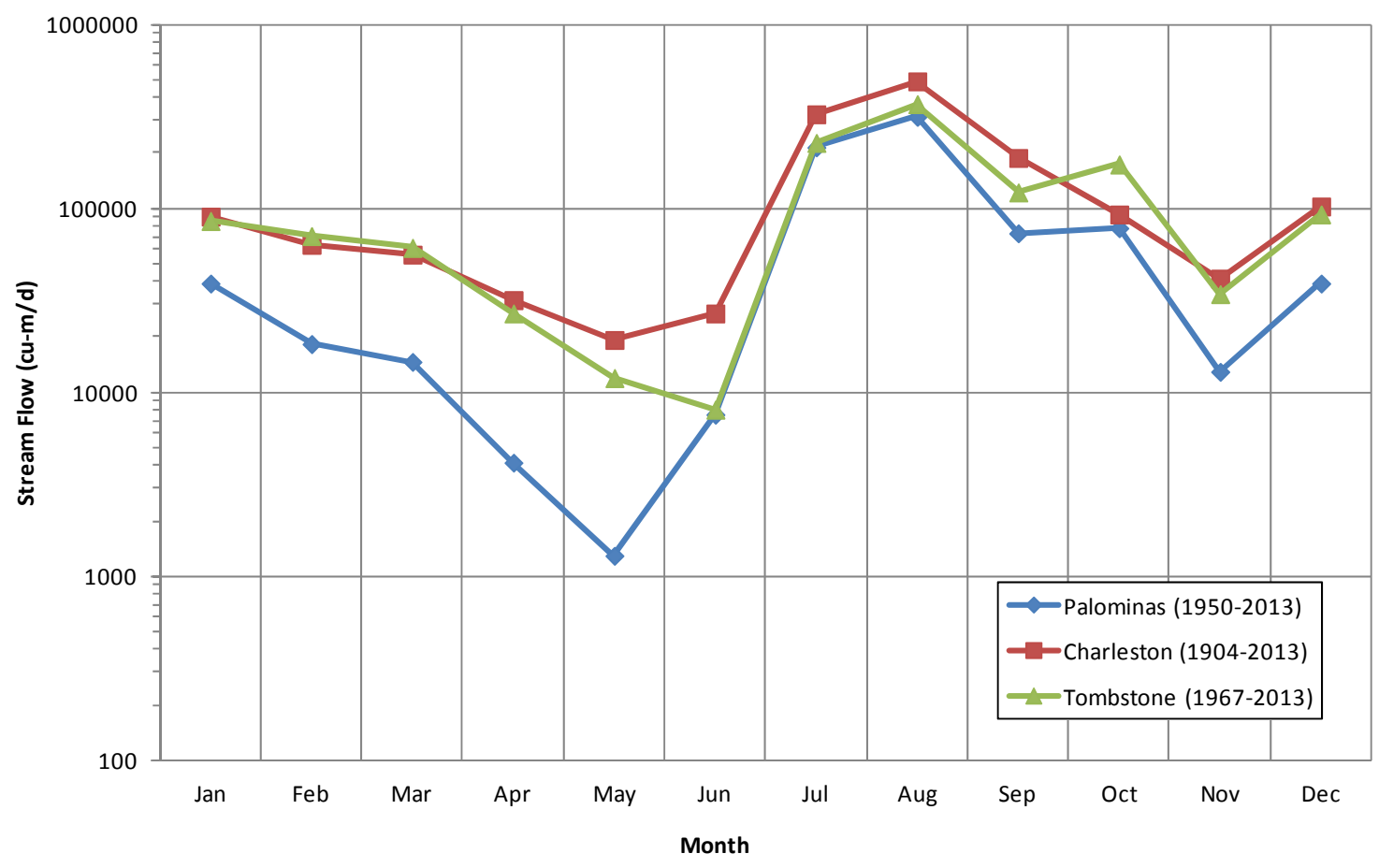

Groundwater discharge from the regional basin-fill aquifer supports baseflows in the river and evapotranspiration by near-stream phreatophytes. Groundwater pumping from that same aquifer supplies a human population in the region that is expected to increase by $46 \%$ by the year 2050 [6]. Sierra Vista, 
Arizona, is the largest municipality in the basin with a population of roughly 45,300 [7]. The U.S. Department of Defense installation at Fort Huachuca borders Sierra Vista on the west and north sides and is a major economic force in the basin [8].

Because of its federal designation and its globally significant biodiversity [9], the SPRNCA has been the subject of extensive hydrological and ecological research. One major finding was that stream flow permanence explained most variance in the basal area of two keystone riparian species, Fremont cottonwood (Populus fremontii) and Goodding willow (Salix gooddingii) [10,11]. As a result, conservation strategies have focused on maintaining or increasing stream flow through reductions in groundwater pumping and managed aquifer recharge at key locations.

\subsection{Hydrological Studies in the Basin}

\subsubsection{General Hydrologic Processes}

The Upper San Pedro River is one of the most intensively studied semi-arid stream systems in the world. Estimated ages of the earliest paleo-Indian sites along the banks of the ancestral San Pedro River date back to 11,000 to 13,000 years ago $[12,13]$. Two Clovis Indian sites have been associated with mammoth kills in the subwatershed, providing some of the earliest dates for human hearths of this culture [13]. The basin has been grazed since the time of the first Spanish explorers in the 1500s [14], and has hosted two major metals mining operations in Tombstone (late 1800s) and Bisbee (1880s-1975), Arizona. In addition, Cananea, Mexico boasts a major copper mine that is currently in active production. The major U.S. Department of Defense Army installation at Fort Huachuca has been in active operation since 1877 and has one of the earliest water rights claims in the basin [15]. More recently, the town of Sierra Vista has grown to include over 45,000 people (including Fort Huachuca). All of these activities have had significant impacts on the landscape and water resources in the basin. Hereford [14] presents a clear description of the land use changes coupled with exceptional periods of flooding near 1900 that led to significant entrenchment and stabilization of the San Pedro River stream channel and dewatering of much of the shallow alluvium of the river channel.

The Walnut Gulch Experimental Station (Figure 1) was established in the northeast area of the subwatershed by the Research Division of the Soil Conservation Service in 1951, and has been the source of continuous instrument-based hydrologic and rangeland studies since that time [16]. In 1966, Brown and others [17] evaluated the water resources of Fort Huachuca, which lies immediately west and north of the City of Sierra Vista (Figure 1). Brown and Aldridge [18] estimated San Pedro River surface discharge from the international boundary with Mexico to its confluence with the Gila River and inputs to the system from tributary inflow and from mountain-front recharge. Much of the assessment of hydrologic resources in the basin that followed came as a byproduct of the development of groundwater models, including those by Freethey [19], Vionnet and Maddock [20], Corell and others [21], Goode and Maddock [22], and Pool and Dickinson [3].

The Arizona Department of Water Resources (ADWR) evaluated the groundwater resources of the basin in 1990 [23], and then again in 2005 [24], in order to determine whether or not the basin should be classified as an Active Management Area (AMA) under the 1980 Groundwater Management Act of Arizona. The ADWR determined that the basin did not meet the statutory criteria for AMA 
designation [23,24], but much of the research that was conducted as part of that assessment remains highly relevant. Pool and Coes [25] described the state of the knowledge of hydrogeology of the subwatershed. As part of that work, an extensive monitoring program was initiated in the subwatershed that included geophysical surveys, ephemeral stream flow monitoring, installation or refurbishment of a number of stream gaging stations, aquifer storage monitoring using microgravity techniques, and basin-wide water level monitoring. Much of this monitoring program continues today.

In support of the conservation mission of the SPRNCA, Section 321 of the Defense Authorization Act of 2004 [26] revised how the federal Endangered Species Act applies to the Fort Huachuca Military Reservation and directed the Partnership to "...restore and maintain the sustainable yield of the regional aquifer [of the Sierra Vista Subwatershed] by and after September 30, 2011.” It also required annual progress reports on these efforts, which were produced for most calendar years from 2002 through 2011 (see [27], for example).

The Partnership sponsored several research reports during this time, which provided the scientific basis for development of the U.S. Geological Survey (USGS) groundwater model by Pool and Dickinson [3]. These studies include Coes and Pool's [28] assessment of ephemeral-stream channel and basin-floor infiltration and recharge, Gungle's [29] analysis of the timing and duration of ephemeral stream flow in the subwatershed, and Leenhouts and others' [30] analysis of the hydrology, vegetation-hydrologic relationships, and evapotranspiration requirements and plant-water sources in the SPRNCA. Leenhouts and others [30] established additional streamflow and groundwater monitoring in the subwatershed, including streamflow stage and permanence data, near-stream alluvial aquifer groundwater and vertical gradient monitoring, and a continuous meteorological and eddy covariance monitoring station for measurement of evapotranspiration in the SPRNCA.

A statistical analysis of the trends in streamflow in the San Pedro River was also published in 2006 by Thomas and Pool [5]. Leake, Pool and Leenhouts [31] used Pool and Dickinson's [3] five-layer groundwater model of the basin to conduct a capture and recharge analysis that mapped the effects of pumping and recharge across the subwatershed on groundwater discharge to the SPRNCA. Kennedy and Gungle [32] analyzed baseflow discharge from the subwatershed at the USGS gaging station near Tombstone, Arizona, at the north end of the subwatershed. Most recently, Lacher [33] updated the Pool and Dickinson [3] groundwater flow model to include recent changes in pumping and artificial recharge in the subwatershed, and simulated the projected effects of population growth-driven increases in pumping on groundwater levels and baseflow through 2105.

\subsubsection{Managed Aquifer Recharge}

In 2006, Stantec [34] developed a Flood Control Urban Runoff Plan for Cochise County that evaluated the size, placement, and efficacy of 30 existing and proposed stormwater detention basins on the west side of the subwatershed functioning as de facto recharge basins. As part of this study, GeoSystems Analysis [35] used a detailed precipitation-recharge-stormwater runoff regression model, based on the U.S. Department of Agriculture's Automated Geospatial Watershed Assessment Tool [36] for the urbanized Coyote Wash watershed in Sierra Vista to estimate the cost, recharge volume, and urban-enhanced runoff for that watershed and several others on the west side of the San Pedro River within the subwatershed. GeoSystems Analysis previously developed the stormwater regression model 
used for the Upper San Pedro Partnership and Cochise County based on detailed AGWA stormwater modeling results for the Coyote Wash watershed located in the City of Sierra Vista [37].

Predictive groundwater modeling [33] indicates that within the next 100 years, two regional cones of depression will merge and reduce groundwater flow from the regional aquifer to the San Pedro and Babocomari (a major tributary to the San Pedro) rivers (Figure 3). These simulations incorporate pumping increases over time that reflect U.S. Census growth rates $[5,6]$ and maintain constant natural recharge and evapotranspiration at 2003 levels (as published in the USGS groundwater model [2]) for the entire 21 st century. Figure 4 a maps the west-east transect A-A' for the simulated groundwater-level profiles shown in Figure 4b. This transect goes through the Sierra Vista-Fort Huachuca cone of depression, and illustrates how simulated groundwater levels at the groundwater divide between the cone of depression and the river have already declined by $17 \%$ since pre-development conditions in 1902 and are predicted to double that level of decline, to $35 \%$, by the year 2100 . These reductions in groundwater levels produce commensurate percent reductions in groundwater gradient (change in head divided by distance) as measured from the same point on the groundwater divide to the river. While gradients directly under the river are not yet showing the same degree of impacts as those farther west, the ultimate outcome of these simulated changes would be greater baseflow losses in some losing reaches, smaller gains in some gaining reaches, and possibly the conversion of some reaches from gaining to losing. The resulting groundwater-driven reduction in baseflow and shallow groundwater would likely impair the dependent riparian systems [33].

Figure 3. Simulated drawdown (m) in the primary regional aquifer of the basin (a) in 2000; (b) in 2050; and (c) in 2100 [33].

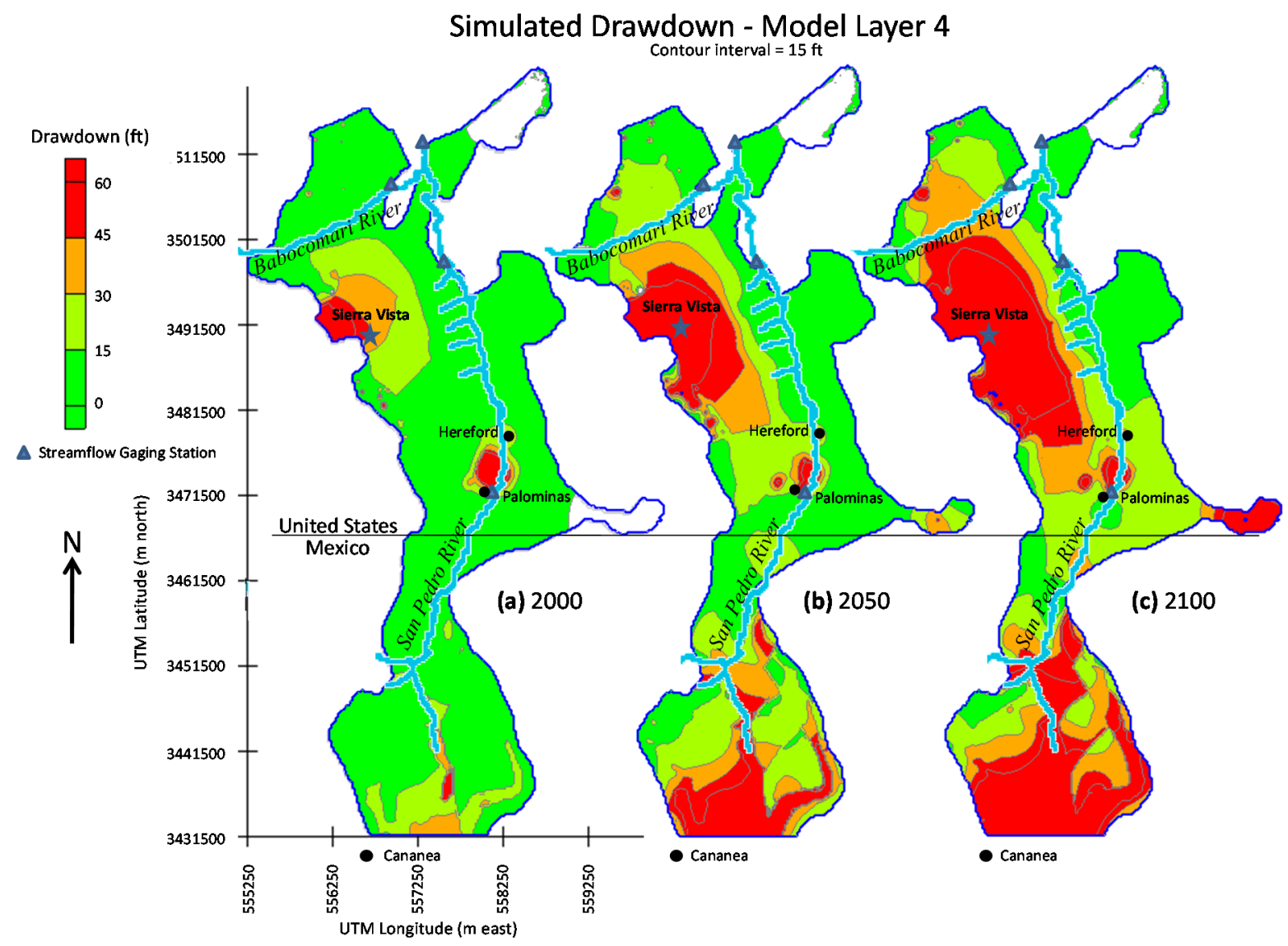


Figure 4. (a) Cross-section A-A' in the center of the Sierra Vista subwatershed (adapted from Stromberg and others [10]; (b) Simulated groundwater-level profiles in 1902, 2013, and 2100 along the A-A' cross-section showing change in gradient ( $\triangle i$ ) from $-17 \%$ in 2013 to $-35 \%$ in 2100 .

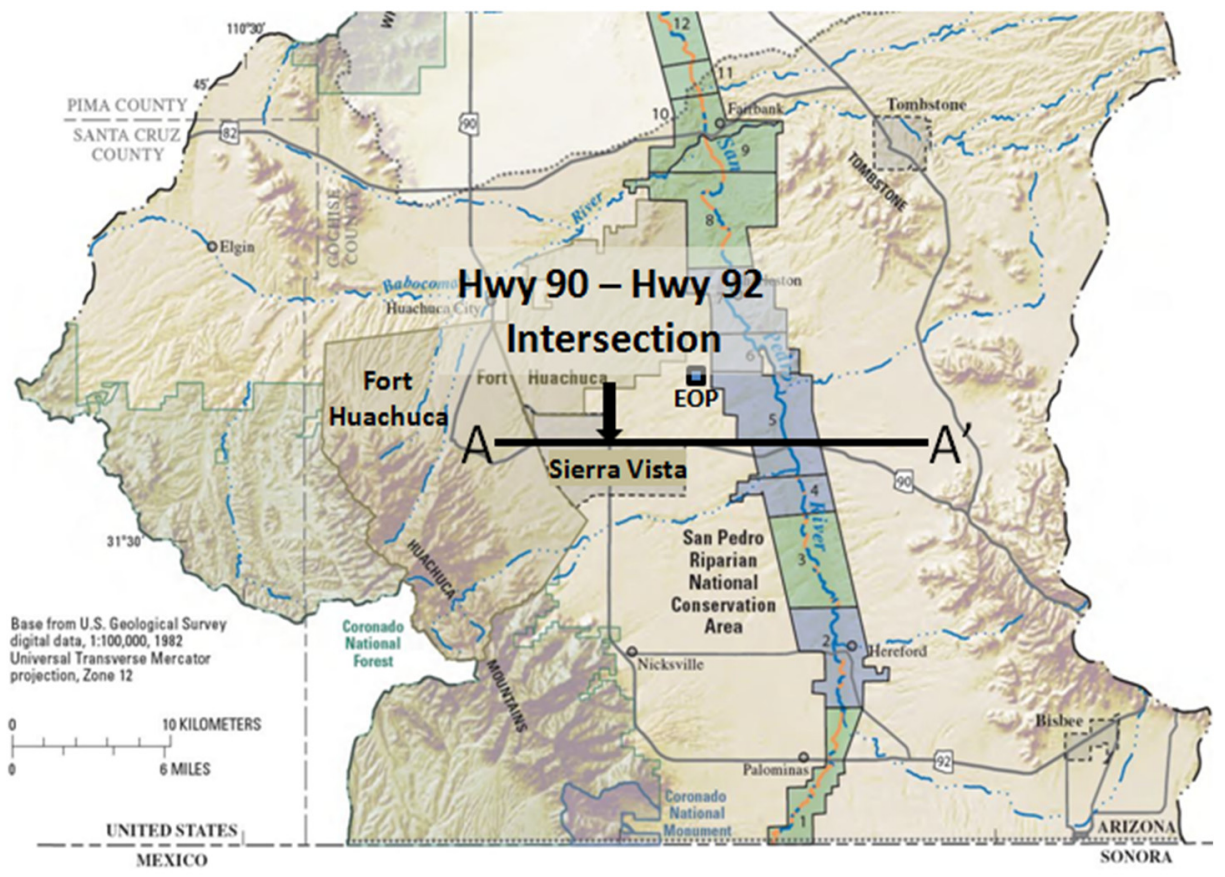

(a)

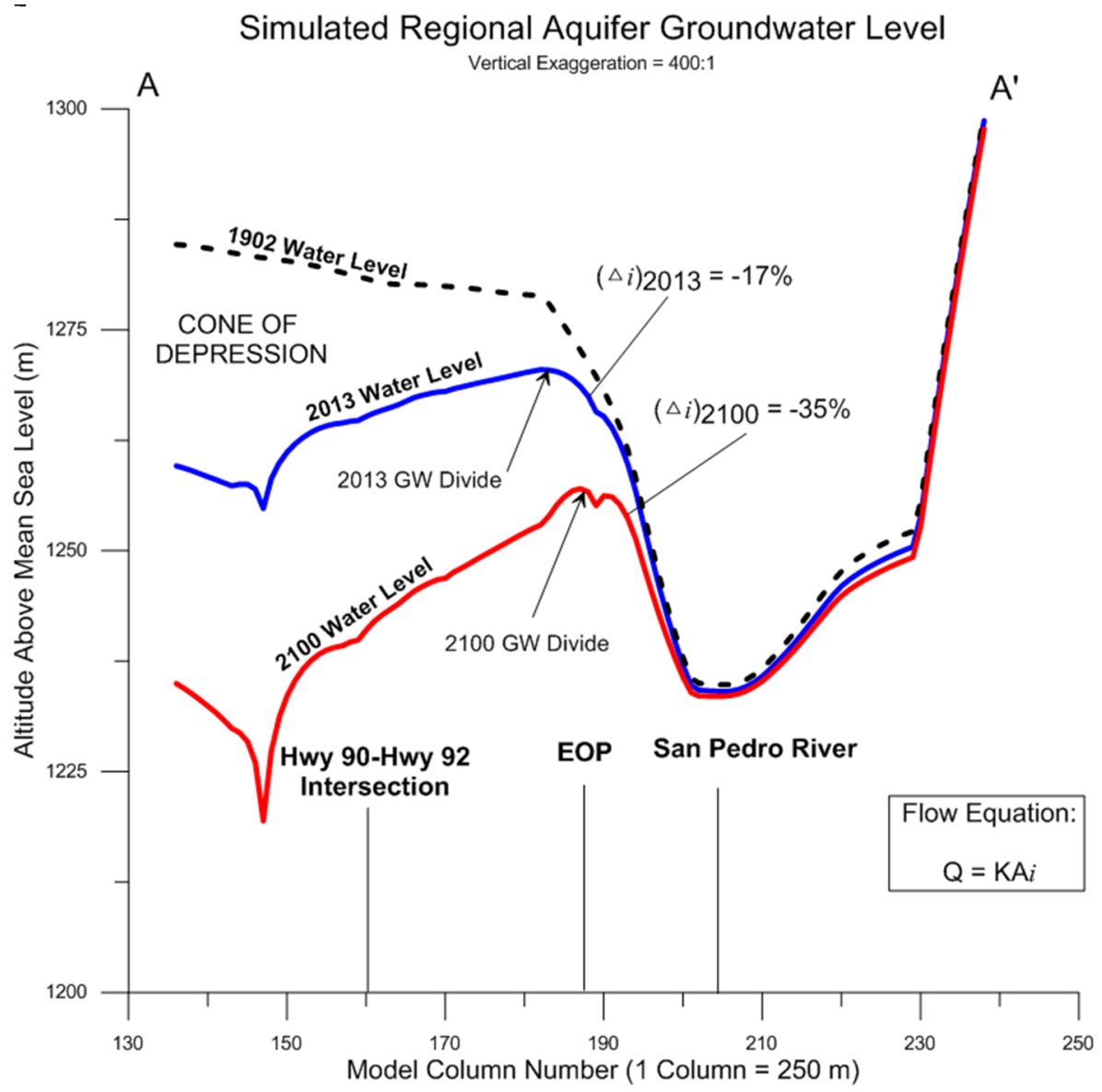

(b) 
One potential solution to the problem of aquifer storage depletion would entail importation of at least some water from a source outside the basin [38]. However, at this time, importation does not appear likely in the foreseeable future (see companion paper by Richter and others [1]). In lieu of a replacement water supply, water managers and stakeholders in the subwatershed recognize the need for a near- to medium-term (i.e., years to decades) intervention to protect stream baseflows and the associated riparian areas.

The City of Sierra Vista has more than 10 years of monitoring data from its Environmental Operations Park (EOP) where treated effluent is recharged at a rate of roughly 9100 cubic-meters per day $\left(\mathrm{m}^{3} / \mathrm{d}\right)$ through artificial wetlands and recharge basins between the City's pumping center and the San Pedro River. This project was designed and constructed to create a groundwater mound to sustain surface water flow and supplement alluvial groundwater levels during low-flow periods [39]. Groundwater modeling that incorporates the EOP recharge data indicates that the project is successfully contributing recharge to both the nearby cone of depression in the regional aquifer and to baseflows in the San Pedro River $[33,40]$. Further groundwater modeling presented in this study suggests that additional recharge projects designed to utilize enhanced urban runoff, treated effluent or other local supplies near the San Pedro and Babocomari rivers may successfully mitigate anticipated pumping-related baseflow depletions for up to 100 years.

While conservation efforts within the subwatershed have reduced consumptive use of groundwater in the basin, particularly on the Fort Huachuca Army installation, the cumulative storage loss in the regional aquifer within the subwatershed from the past half century of pumping, estimated to exceed $800 \mathrm{MCM}$ (refer to explanation provided in Section 2.3.2) remains a threat to the San Pedro River and its tributaries by intercepting mountain-front recharge and by reducing the groundwater gradient that drives aquifer discharge to the rivers. Because of this storage deficit and the fact that virtually all water use in the subwatershed depends on groundwater, almost any level of continued groundwater use poses an increasing risk of stream and riparian evapotranspiration capture over time.

\subsubsection{Streamflow Permanence Monitoring}

Direct measurement of baseflow, defined as the portion of streamflow derived from groundwater, is complicated by the effects of prolonged storm and/or snowmelt runoff (which tend to exaggerate baseflow estimates) and evapotranspiration (which reduces apparent baseflow). Acknowledging these complexities, practitioners have found that inter-annual stream-flow permanence in a river system that experiences intermittent drying in some reaches is a useful indicator of both hydrologic and ecological conditions in the San Pedro basin. Using a technique called wet/dry mapping, analysis of surface water presence (strict criteria are used to ensure consistent definition of surface water versus minimal puddles) during the driest time of year (mid June in the San Pedro Basin) reveals areas with high year-to-year variation in the length of surface wetting (Figure 5). By limiting the influence of storm events as much as possible, and assuming no significant changes in the condition of the riparian forest, these variations in wetted length are believed to be the best available physical expression of local groundwater conditions and may provide early warning of ecological changes [41]. 
Figure 5. Wet/dry results from the San Pedro Riparian National Conservation Area. The heavy river line shows reaches, which were wet in June 2013. Bars on right side represent wet reaches for each year, 1999-2013. Labels on the far right identify the 10 analysis segments, each covering $8.1 \mathrm{~km}$. The four green properties (parcels 1 through 4) on map were recently acquired for groundwater protection and recharge projects. Redrawn from Turner and Richter [41].

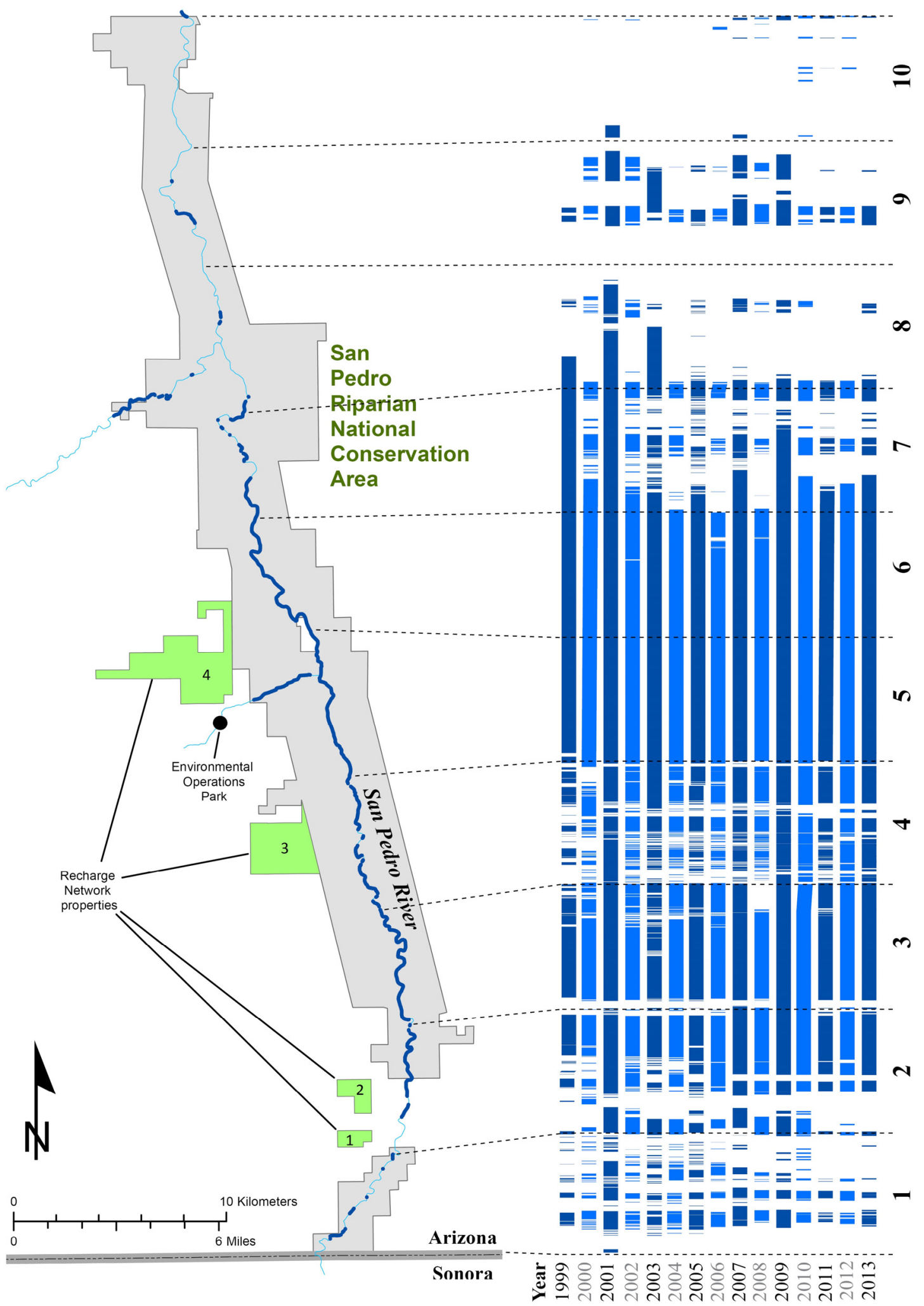


Wet/dry mapping, as applied in the San Pedro River basin, uses citizen scientists annually to map the spatial extent of surface water in a river or stream. The method provides a comprehensive snapshot of conditions for the whole river at the same date each year, allowing comparisons of year-to-year variability [41]. Beginning in 1999, staff from The Nature Conservancy and the U.S. Bureau of Land Management coordinated volunteers to map the spatial extent of surface water within the SPRNCA. The exact dates varied slightly, but mapping was conducted during the third weekend of June each year to coincide with the lowest flow before the expected start of the summer rainy season. Through the years, progressively more of the river and its tributaries have been surveyed, increasing to $231 \mathrm{~km}$ of the mainstem and $266 \mathrm{~km}$ of tributaries in 2013. This paper addresses only the $80 \mathrm{~km}$ of mainstem river surveyed through SPRNCA.

\section{Methods}

\subsection{Wet/Dry Mapping}

Surveyors walked predetermined segments of the river, recording the coordinates of beginning and end points of all surface water segments greater than or equal to $9.1 \mathrm{~m}$ long using paper data forms and consumer-grade Global Positioning System units. They disregarded any dry gaps less than $9.1 \mathrm{~m}$ long in otherwise wet reaches. The resulting point coordinates were imported to a Geographic Information System (ArcGIS, Environmental Systems Research Institute, Redlands, CA, USA), and snapped to the closest points on a linear representation of the river. To identify localized trends, organizers partitioned the SPRNCA into 10 equal segments, $8.1 \mathrm{~km}$ long. Segments were analyzed for probability of trend using the Mann-Kendall test. For graphic purposes, we calculated and display the Sen estimate of linear trend (detailed methods are provided by Turner and Richter [41]). Starting in 2007, maps and summary data from the wet/dry surveys have been posted each year to a web site (http://www.azconservation.org) for public distribution.

Results from wet/dry mapping in the SPRNCA (Figure 6), as a whole, show about half the river has permanent surface water with some year-to-year variation but no trends. However, analysis of the smaller segments shows considerable variation Turner and Richter [41]). The southernmost segment, Segment 1, displays a significant downward trend, while Segment 2 trends upward. Most of the other segments have either year-to-year up/down results or a stable condition without trend. The distribution of wet and dry reaches has provided a simple way to prioritize and site conservation actions aimed at reduced groundwater pumping and managed aquifer recharge, as described in Section 3 below. Wet/dry mapping data are also expected to provide a quantitative measure of conservation progress after those strategies are implemented. 
Figure 6. Total wetted lengths for the 10 analysis segments in Figure 3. Segment numbers increase from south to north (downstream). Revised from Turner and Richter [41].

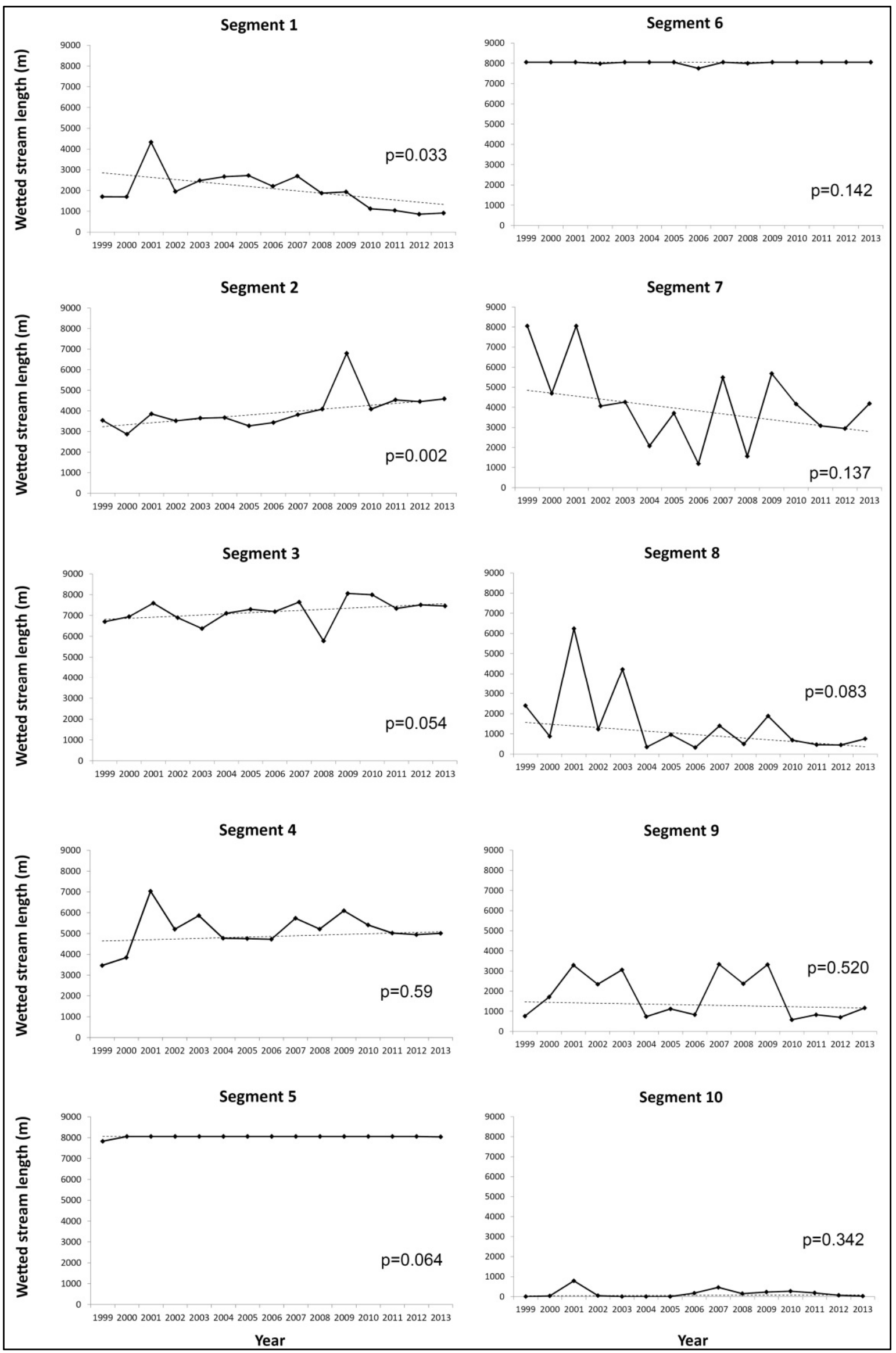




\subsection{Capture Mapping}

\subsubsection{Overview of Capture}

The Upper San Pedro River's position near the geographic center of an alluvial basin makes it a classic example of basin-fill hydrology. The existence of a major pumping center at Sierra Vista/Fort Huachuca between the primary area of recharge for the subwatershed (the Huachuca Mountains on the western boundary) and the river (Figure 1) also makes the basin a classic case study in groundwater capture. Capture is the increase in recharge to, and (or) decrease in discharge from, a basin that eventually occurs as a result of groundwater pumping. Theis [42] first addressed the consequences of groundwater pumping from a previously undeveloped system in 1940:

"Under natural conditions...previous to development by wells, aquifers are in a state of approximate dynamic equilibrium. Discharge by wells is thus a new discharge superimposed upon a previously stable system, and it must be balanced by an increase in the recharge of the aquifer, or by a decrease in the old natural discharge, or by loss of storage in the aquifer, or by a combination of these."

Lohman and others [43] further clarified the definition of capture from Theis' description:

"The decrease in discharge plus the increase in recharge is termed capture."

This definition of capture may be written as:

$$
\text { Capture }=\Delta R+\Delta D
$$

where $\boldsymbol{\Delta R}$ and $\boldsymbol{\Delta D}$ equal the increase in recharge and the decrease in discharge, respectively.

In the Upper San Pedro basin, as in many basins in the southwest deserts of the United States, aquifer storage is plentiful as a result of recharge over thousands of years of depositional history, but potential sources of capture are limited primarily to reductions in riparian ET, reductions of groundwater discharge to streams (baseflow), and direct capture of streamflow. The numerical partitioning of extracted groundwater into its constituent sources through a water-budget process is a common and fraught practice in many water-short areas of the United States. Bredehoft, Papodopulos, and Cooper [44] attributed this practice to "perhaps the most common misconception in groundwater hydrology" which is "that a water budget of an area determines the magnitude of possible groundwater development." Under this line of reasoning, many water managers have concluded that all water entering the system as natural recharge is available for extraction without long-term deleterious effects. Brown [45] addressed the problem with this argument through an example of a well whose cone of depression eventually expands to intersect a stream in which he demonstrated that,

"...the rate at which the hydrologic system reaches a new steady state depends on the rate at which the natural discharge [in his example to a stream] can be captured by the cone of depression."

Figure 7 illustrates the evolution of a groundwater system which receives natural recharge (through precipitation) at a fixed and limited rate, $\boldsymbol{R}_{\boldsymbol{0}}$, and discharges to a stream as baseflow at a rate of $\boldsymbol{D}_{\boldsymbol{0}}$. In Figure $7 \mathrm{a}$, the system is in equilibrium prior to any significant groundwater development. In this natural 
state of equilibrium (roughly prior to 1940 in the Upper San Pedro basin [3]) recharge equals discharge (Equation (2)):

$$
R_{0}=D_{0}
$$

Figure 7. (a) Groundwater discharging to stream under equilibrium conditions; (b) Pumping at rate $\mathrm{Q}$ from a well intercepting groundwater that would have discharged to the stream under equilibrium conditions; $Q$ is roughly equal to the rate of change in aquifer storage $(\Delta S)$ plus reduced groundwater discharge to the stream $(\Delta \mathrm{S})$; (c) Pumping at the same rate $(\mathrm{Q})$ under a new equilibrium condition. Now, pumping is reducing groundwater discharge to the stream $(\Delta D)$ and inducing recharge directly from the stream $(\Delta \mathrm{R})$, and aquifer storage depletion ceases $(\Delta \mathrm{S}=0)$. Adapted from Winter and others ([46], Box C, p. 15) and from Heath ([47], p. 33).
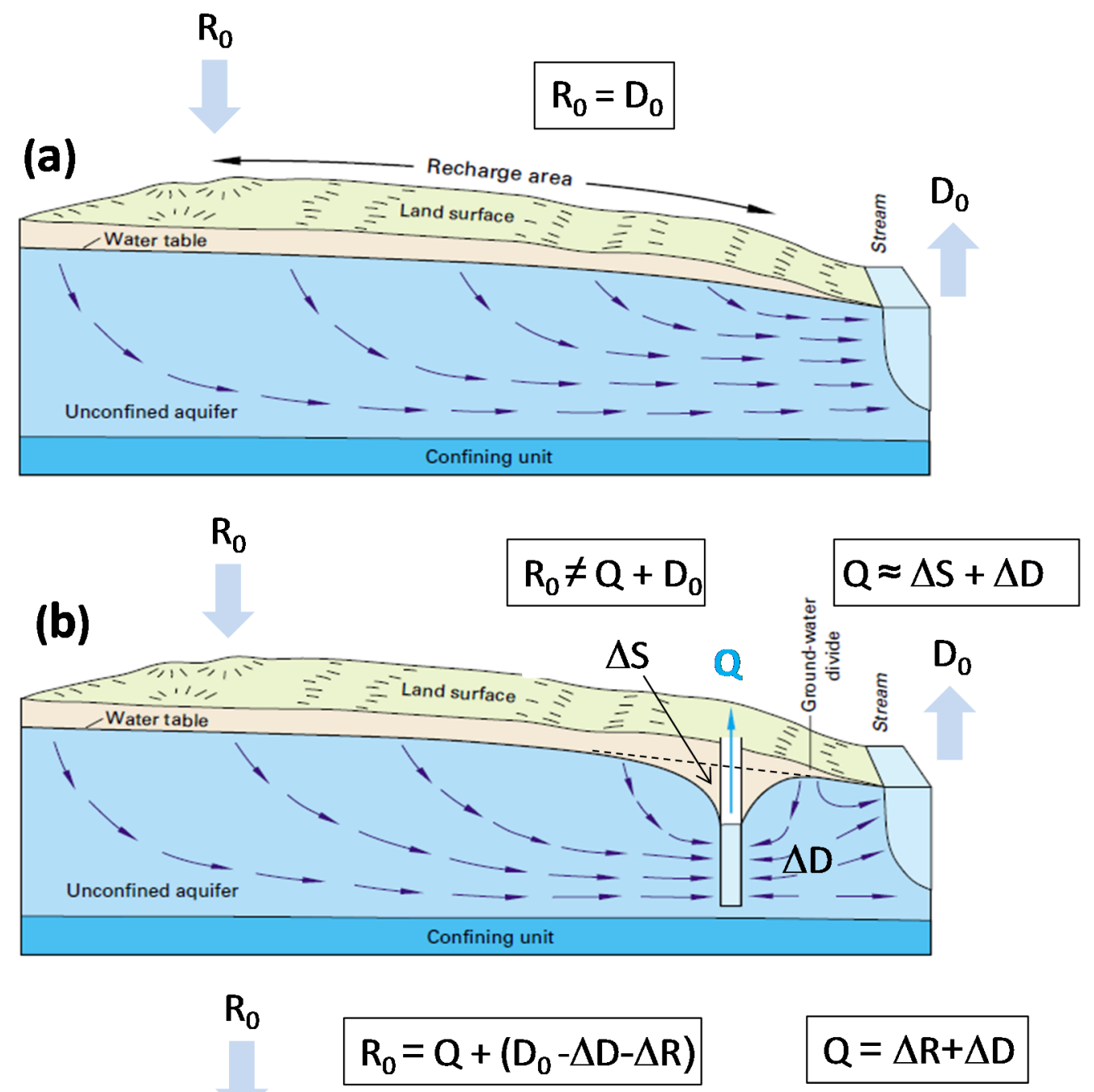

(c)

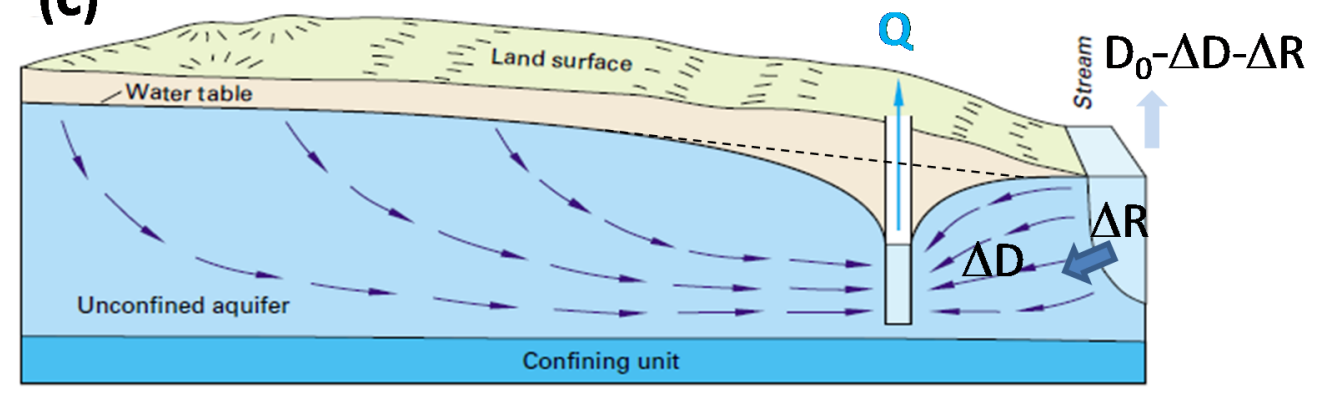


In Figure 7b, pumping at a rate of $\boldsymbol{Q}$ is superimposed on the system, producing a rapid rate of change in aquifer storage near the well $(\boldsymbol{\Delta S})$ and intercepting some groundwater that would otherwise have discharged to the river $(\boldsymbol{A D})$, but having no immediate effect on discharge to the stream $\left(\boldsymbol{D}_{\boldsymbol{0}}\right)$ due to the persistence of a groundwater "high" between the well and the river. At this point, pumping is roughly equivalent to the rate of change in aquifer storage plus the reduction in groundwater discharge to the stream (Equation (3)).

$$
\boldsymbol{Q}=\Delta \boldsymbol{S}+\Delta \boldsymbol{D}
$$

and recharge and discharge are no longer in balance (Equation (4)):

$$
R_{0} \neq Q+D_{0}
$$

After some time (Figure 7c), the cone of depression intercepts the stream and reverses the gradient of the groundwater so that it now flows toward the well from all directions, directly capturing streamflow. Even though the pumping rate $(\boldsymbol{Q})$ remains constant, recharge from precipitation also remains fixed at $\boldsymbol{R}_{\boldsymbol{0}}$, so the only sources of water for extraction come reduced groundwater discharge to the stream, capture (increased recharge) from the stream, itself, and possibly some additional aquifer storage. A new equilibrium is achieved when aquifer storage is no longer being depleted $(\boldsymbol{\Delta S}=\mathbf{0})$ and pumping is balanced by the capture of stream flow and decreased discharge to the stream (Equation (5)):

$$
\boldsymbol{R}_{\mathbf{0}}=\boldsymbol{Q}+\left(\boldsymbol{D}_{\mathbf{0}}-\Delta \boldsymbol{D}-\Delta \boldsymbol{R}\right)
$$

or,

$$
\boldsymbol{Q}=\Delta \boldsymbol{R}+\Delta \boldsymbol{D}
$$

Lohman [48] identified another potential source of capture not expressly described above. He referred to it as "salvaged rejected recharge from precipitation." This potential source of capture would comprise a new source of recharge $(\Delta \boldsymbol{R})$ as described in Equations (1) and (6). In the case of a large alluvial basin like the San Pedro, where much of the shallow alluvial aquifer is separated by a thick sequence of confining materials from the underlying regional aquifer, this source of potential capture would derive from the occasional replenishment of the shallow alluvial aquifer during runoff from one or more very large precipitation events. Runoff exceeding $25 \mathrm{M}$ cu-m/d occurs roughly every 5 to 6 years at the Palominas station (Figure 1), so any excess alluvial aquifer storage opened up by groundwater pumping could capture flood flows that would otherwise have been rejected and remained in the stream.

For the period 2000 to 2009, Kennedy and Gungle [32] found that alluvial aquifer storage changes that govern baseflow measured at the Tombstone stream-flow gaging station (near the far downstream end of the study area (Figure 1)) were a function of upstream riparian ET and summer precipitation. Although they did not identify groundwater pumping as a clear source of baseflow decline in that reach over that short period, they do caution that, "[c]ontinued regional groundwater pumping will, however, eventually lead to a decline in the contribution of regional groundwater to base flow." This contrast between the interannual scale of fluctuations in alluvial aquifer storage and the multi-decadal scale of changes in regional aquifer discharge is highly significant for long-term water management planning. Our study focuses on these longer-term regional aquifer changes, but acknowledges the importance in improving our understanding of the linkages between sources of capture at different temporal and spatial scales. 
Groundwater simulations [3,33] indicate that the Upper San Pedro basin is transitioning between the second and third scenarios illustrated in Figure 7. Of course, streamflow is not the only potential source of capture in most groundwater basins, and may not be available at all, as in basins where the streambed has lost connectivity with the underlying aquifer. Other potential sources of capture include riparian evapotranspiration, groundwater inflow from boundary sources, and groundwater outflow from the basin. Because groundwater and surface water systems operate on such different time scales, stresses on a groundwater system may not manifest as baseflow depletions for many years. Unfortunately, "in many circumstances the dynamics of the groundwater system are such that long periods of time are necessary before any kind of an equilibrium condition can develop. In some circumstances the system response is so slow that [groundwater] mining will continue well beyond any reasonable planning period" ([44], p. 55-57). The goal of the study described in this paper is to anticipate the future impacts of 20th and 21st century pumping on the San Pedro River and to develop a strategy to mitigate those effects as they occur.

\subsubsection{Development of Capture Map}

Leake and others [31,48] developed a unique tool that utilizes the Pool and Dickinson [3] regional groundwater flow model to assess simulated pumping-induced capture of streamflow, spring discharge, and riparian ET across the model domain in response to a unit pumping stress at every location in the model, and presents the results as a map overlay with colored contours representing the amount of capture, as a fraction of the pumping rate, after pumping for a specified amount of time (Figure 8). Leake and others [49] provide detailed steps for developing a capture map using a groundwater model. Alternatively, capture for a given location can be calculated as the pumping time needed to reach a depletion-dominated supply (the time at which capture begins to provide greater than $50 \%$ of total groundwater pumped). A typical time scale for a basin in the American Southwest might be 0 to 100 years [50]. Capture map development can also be run in reverse, providing estimates of the total increase in streamflow, riparian evapotranspiration, and spring flow, as a fraction of recharge rate, after recharging at a unit rate for a specified amount of time [51]. The two are not necessarily the inverse of each other. Leake and others [31] calculated stream and riparian area capture resulting from pumping in the lower basin fill primary aquifer (layer 4 of the 5-layer groundwater model [3]) in the Upper San Pedro basin. They used the same method to calculate response in the stream/riparian area from recharge applied to the top-most layer of the model that overlies the extent of layer 4 (layers 1, 2, or 4).

\subsubsection{Use of Capture Map in the San Pedro Basin}

Richter and others [1] discuss the evolution of the capture map concept and its use in policy development within the basin. While the capture map does not replace groundwater modeling, it is a simple, intuitive tool that permits the layman to gain a better understanding of the degree of connectivity between the groundwater system and the river. Policy makers and stakeholders embraced the capture map in the San Pedro basin as a guide for various preliminary decisions on community development and ecological restoration. 
Figure 8. Computed capture (as a percentage of pumping rate) of streamflow, riparian evapotranspiration, and spring flow that would result for withdrawal of water from model layer 4 at a constant rate for 10 years. The color at any location represents the fraction of the withdrawal rate by a well at that location that can be accounted for as changes in outflow from and or inflow to the aquifer for model boundaries representing streams, riparian vegetation, and springs. Redrawn from Leake and others [31].

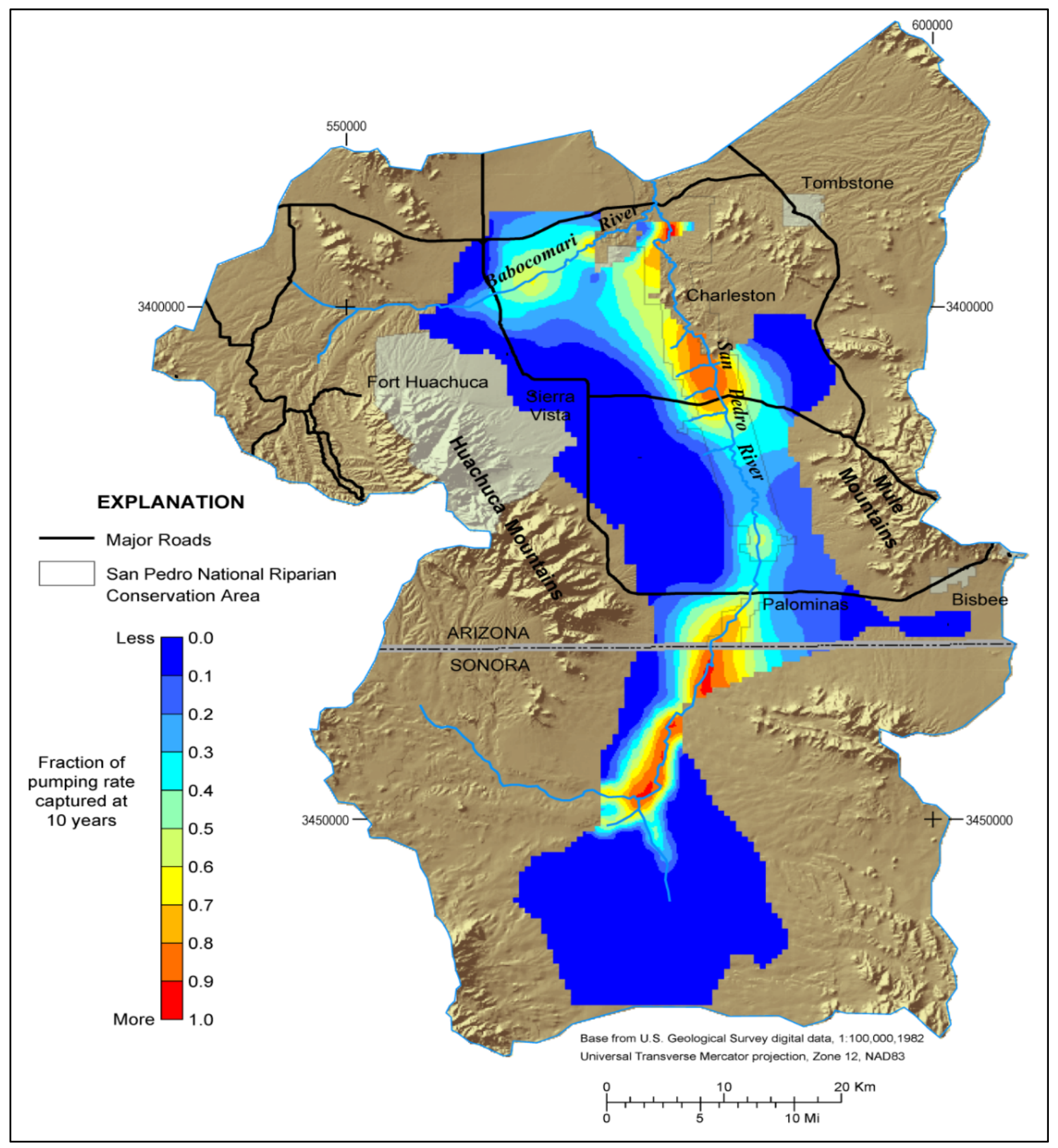

\subsubsection{Advantages/Disadvantages and Limitations of the Tool}

Capture maps highlight where pumping will have the greatest impact on a water resource (such as a river) within a specified period of time, and thus make an excellent preliminary planning tool for water managers, commercial and residential developers, and conservationists who can benefit from reducing 
the immediate impacts of groundwater pumping. The similarly constructed recharge map provides similar planning benefits, offering the planner an initial overview of the most advantageous sites for storm-water, treated effluent, or other recharge facilities.

Despite the value of capture maps for communicating some complex hydrologic concepts to lay audiences, details about specific volumes and rates of capture for specific sources/sinks in the basin cannot be extrapolated directly from this tool. Capture maps, based on linear superposition, reflect the assumption of constant hydrologic properties of the aquifer, assuming that pumping causes no non-linear behavior in the hydrologic system. This limitation, and the fact that each cell of the model is stressed in isolation to make the map, means that capture maps cannot replace the use of a full groundwater model for examining the cumulative impacts of various stresses and sinks that change over time or that cause nonlinearities in hydrologic properties or boundary conditions.

\subsection{Near-Stream Recharge Simulations}

\subsubsection{Description of Model}

Simulations in this study used the most recent and most sophisticated groundwater flow model of the Upper San Pedro Basin available [3]. Although the model area includes all of the $4500-\mathrm{km}^{2}$ basin of which $40 \%$ is in Mexico, this study focuses on the Sierra Vista subwatershed within the United States (Figure 1). This MODFLOW-2000 [52] model is based on a uniform $250 \mathrm{~m} \times 250 \mathrm{~m}$ grid spacing oriented north-south in alignment with the basin. The stream is represented by the Stream Package [53], hydraulic flow is modeled with the Layer Property Flow (LPF) package, and riparian evapotranspiration is modeled with the Evapotranspiration (EVT) Package of MODFLOW-2000. The two-season model reflects the seasonal significance of evapotranspiration in the riparian zones along the San Pedro and its tributaries. The cool season extends from mid October to mid March, and the warm season runs from mid March through mid October [3].

As with all groundwater models, this model has several limitations. Most significantly, it does not simulate flood flows, which are known to contribute significant recharge to the alluvial aquifer near the center of the basin as well as along some ephemeral tributaries to the mainstem of the San Pedro River. This seasonal "topping off" of the shallow alluvial aquifer may support baseflows in the river through one or more dry seasons, and is an important component of the riparian system. While this shortcoming means that the model tends to underestimate true baseflow (regional aquifer plus shallow alluvial aquifer contributions), it does not preclude the model as a useful tool for analyzing the effects of pumping on the regional aquifer's contribution to baseflow. For this reason, the term "baseflow" in this study refers strictly to that component of total baseflow that derives from the regional aquifer where most of the pumping in the basin occurs.

Figure 9 illustrates the conceptualized hydrogeologic cross section (upstream view) of the subwatershed and shows how the model layers correspond to that conceptualization. The model structure includes five layers in a stacked-bowl configuration representing sediment accumulation in the structural depression between two bounding mountain ranges, as is typical of the Basin and Range province of the western United States [3]. Only model layer 5 is found throughout the entire region (Figure 10). 
Figure 9. Conceptualized cross section of basin showing model layers. Adapted from Figure 3 in Pool and Dickinson [3]).

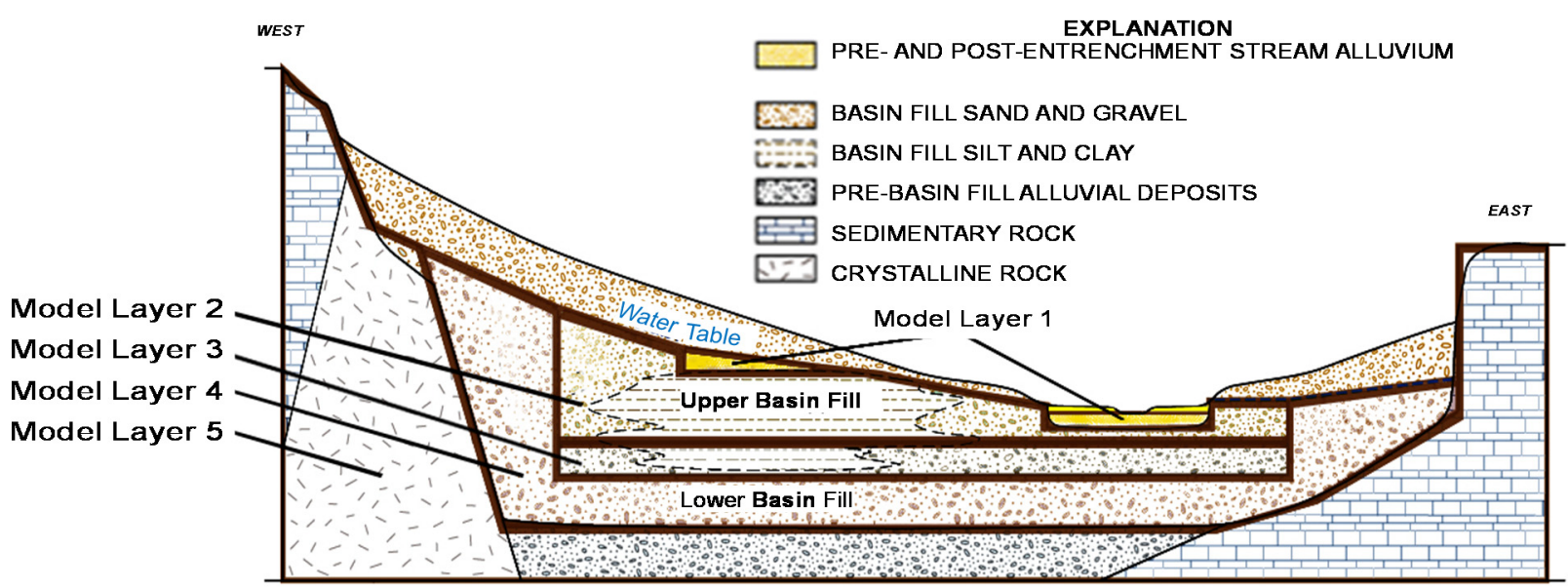

Figure 10. Model layers [2] in plan view with San Pedro River intersecting various layers. Light blue line represents river location but does not necessarily signify perennial flow.

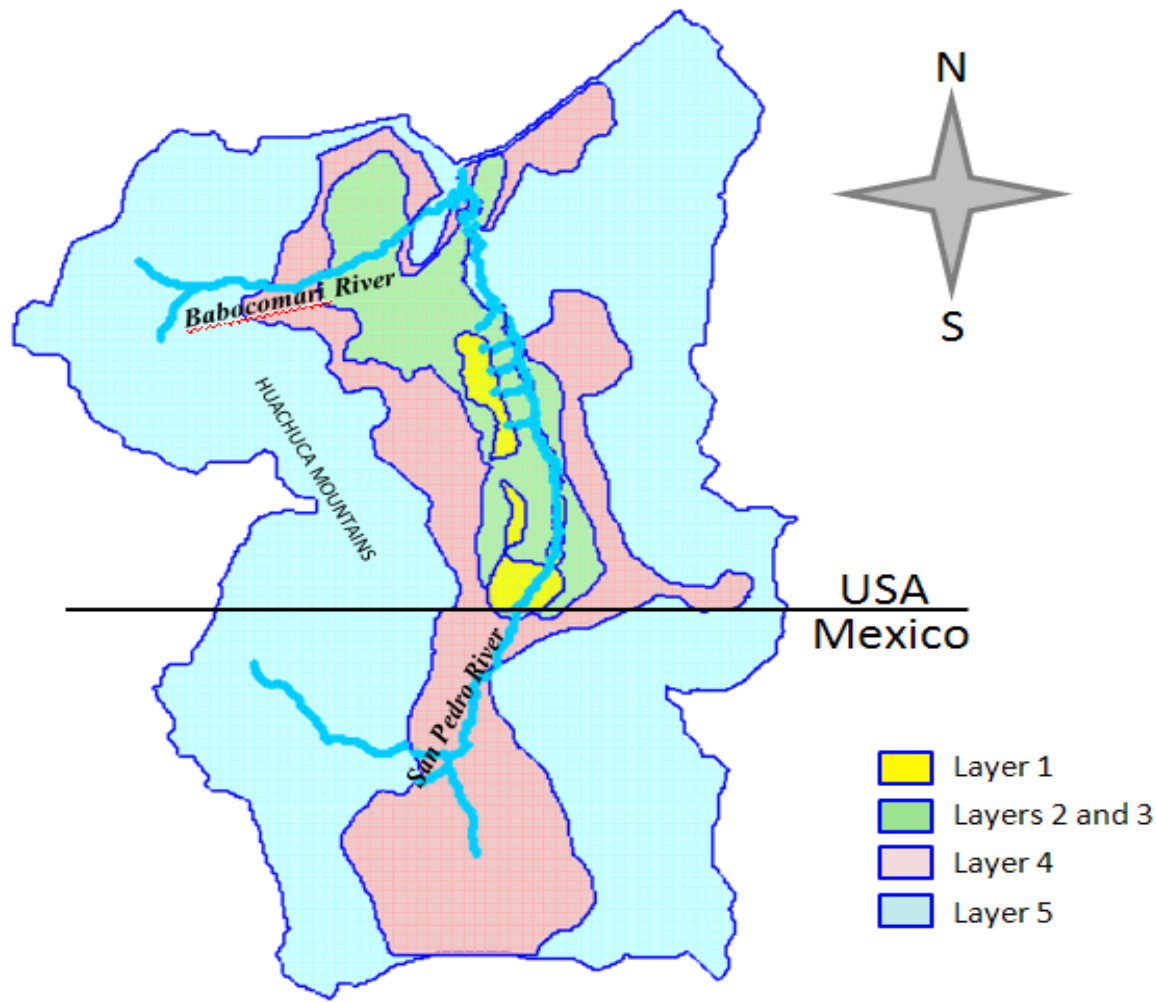

\subsubsection{Use of Model in Water Resources Assessments}

Initial groundwater modeling efforts by Pool and Dickinson [3] simulated transient groundwater levels and baseflows in the basin resulting from 20th-century (1902-2003) pumping and changes in riparian evapotranspiration associated with climate and evolving geomorphology of the stream channel [14]. These simulations reflected the development of a major cone of depression under the Sierra Vista/Fort Huachuca population center on the west side of the river, and a smaller area of groundwater 
depletion very close to the river near the communities of Palominas and Hereford, where agricultural pumping occurred for many decades (Figure 3a). The effects of groundwater use in Mexico also manifest as an irregular cone of depression progressing northward from the south edge of the regional aquifer.

Simulations by Lacher [33] built on the work of Pool and Dickinson [3] and projected pumping through the 21 st century based on population projections developed by the Arizona Department of Commerce [54] and TischlerBise [55], and calculating the total drawdown (Figure 3) and change in baseflow over the 1902-2100 period (Figure 11). These simulations predicted widespread increases in aquifer storage depletion across the western side of the basin during the 21 st century (Figure $3 b, c)$. They also quantified projected declines in baseflow in the basin over the next 100 years due to pumping and evapotranspiration, as well projected increases in baseflow until about 2050 resulting from the recharge facility at the City of Sierra Vista's Environmental Operations Park (EOP) (Figure 11b).

Figure 11. Simulated baseflow capture from 1902 to: (a) 2000; (b) 2050; and (c) 2100. Capture is cumulative [33] and measured in cu-m/d. EOP indicates location of Sierra Vista's Environmental Operations Park wastewater recharge facility.

\section{Simulated Cool-Season Baseflow Capture} Cumulative Since 1902
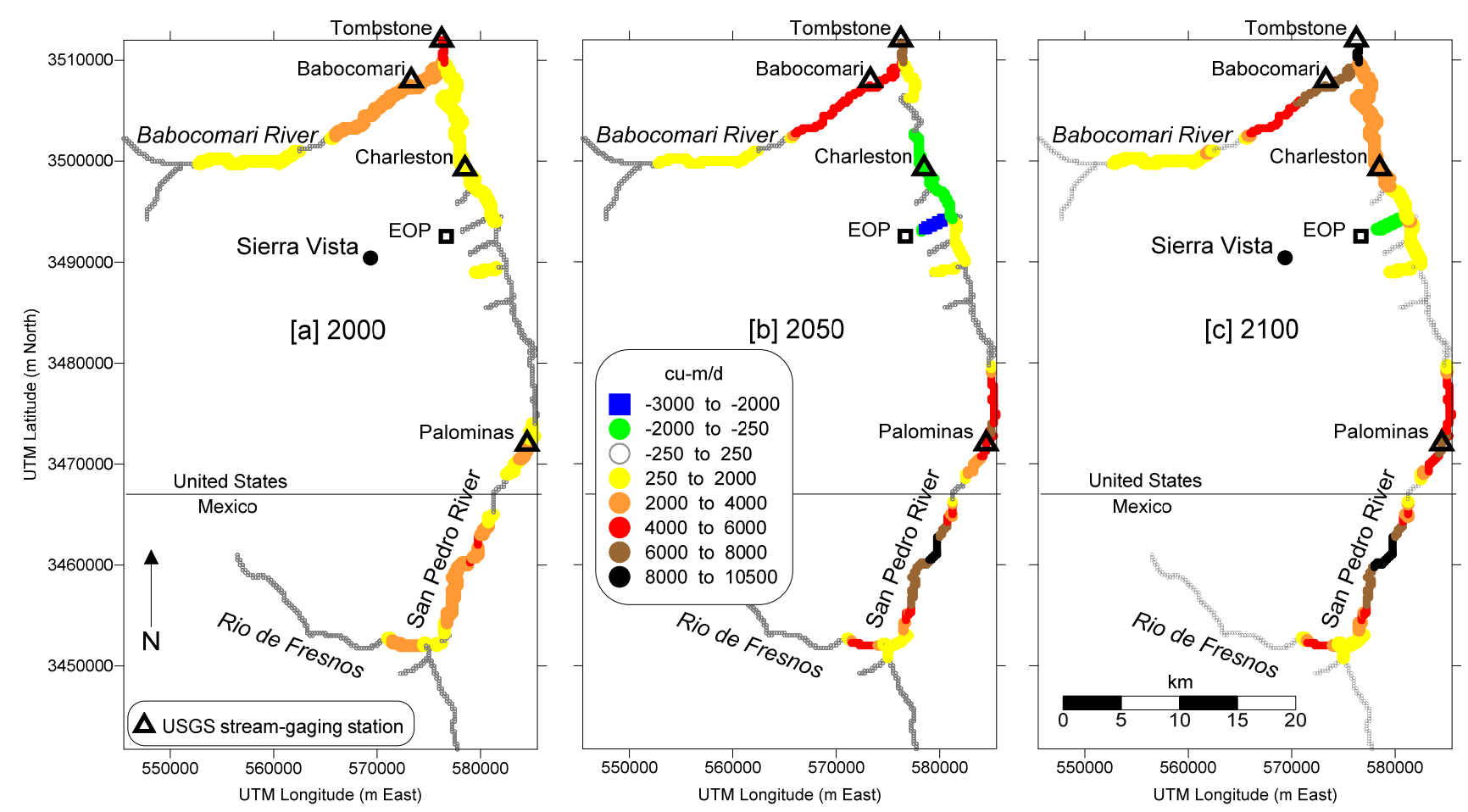

Water budget calculations and groundwater simulations suggest that cumulative total groundwater depletion is presently on the order of $800 \mathrm{MCM}$ in the subwatershed with annual net storage loss over the last decade on the order of 5 to $7 \mathrm{MCM}[56,57]$. Policy makers in the subwatershed have considered the feasibility of importing water at a maximum rate of roughly $37 \mathrm{MCM} / \mathrm{yr}$ [38]. However, even that most optimistic rate of importation would require nearly 25 years to bring the subwatershed's cumulative water budget back into balance. In the meantime, ongoing pumping-induced baseflow capture would continue to depress the groundwater gradient between the pumping centers and the river (Figure 4) further reducing baseflows. 


\subsubsection{Near-Stream Simulated Recharge Site Selection}

Although artificial recharge of urban-enhanced runoff through detention basins has long been considered a viable option for mitigating impacts of groundwater pumping, the basins have previously been designed to target the active cone of depression in the Sierra Vista/Fort Huachuca area [34] rather than the river. The concept of simulating targeted near-stream recharge arose from the process of quantifying the pumping-induced capture of baseflow (i.e., a reduction of groundwater discharge from the regional aquifer to the river) over time using the regional groundwater flow model [33]. With simulated current baseflow capture for the entire basin and projections of aquifer storage and baseflow capture trends over the next century, near-stream recharge was identified as a potential mechanism for addressing projected baseflow "deficits" (declines from 2003 (end of transient model calibration period) baseline values) in targeted areas of the basin.

Taken together, the suite of hydrologic tools pointed to sections of the San Pedro River where greater protection was warranted and where meaningful impacts - such as converting an intermittent stream reach into perennial reach — could be made. Simulations with the groundwater model [58] suggested that developing a distributed, strategically located network of recharge projects near select river reaches might result in groundwater mounding that would effectively compensate for baseflow capture, thus, protecting baseflow and the riparian vegetation community from the anticipated effects of pumping for several decades or more.

\subsubsection{Application of Recharge Models}

A small core team of technical experts within the Upper San Pedro Partnership Technical Committee selected three trial sites for simulating hypothetical recharge near the river: (1) Palominas; (2) Garden Canyon; and (3) Babocomari (Figure 12). The site selection process was informed by both simple geography (upper, middle, and lower part of the subwatershed) and current and projected baseflow capture in the river system. Simulated recharge at each trial site consisted of surface recharge over four $250 \mathrm{~m} \times 250 \mathrm{~m}$ model cells $\left(0.25 \mathrm{~km}^{2}\right)$ for the period 2012-2111. For each of the three trial sites shown in Figure 12, the recharge simulation investigation involved increasing recharge, as needed, to prevent any decline in baseflow below baseline (2003) levels downstream of the site over the simulation period while also preventing simulated surface flooding at the trial site.

Starting with $0.62 \mathrm{MCM} / \mathrm{yr}$, simulated recharge at each site was incrementally increased, and baseflow response tested, until baseflow downstream of each site remained at or above 2003 levels for the 100-year simulation period. Figure 13 shows simulated change in the cool season (October-March) baseflow from 2003 (end of the transient calibration period) conditions in the years 2030, 2050, 2070, and 2111. As the decreasing cool (blue and green) colors in the northern half of the subwatershed over time indicate, baseflows are predicted to fall below 2003 levels in all of the mainstem San Pedro River and on the Babocomari by 2111. Recharge at the Sierra Vista EOP successfully maintains simulated baseflows in the mainstem above 2003 levels until at least 2070, but the impacts of pumping (deepening and widening cone of depression) overwhelm the recharge benefits by about the turn of the century. 
Figure 12. Simulated trial recharge sites (Babocomari, Garden Canyon, and Palominas) in the Sierra Vista subbasin. Riparian condition class reaches delineated within the SPRNCA [10]. Adapted from Figure 42 in Stromberg and others [10].

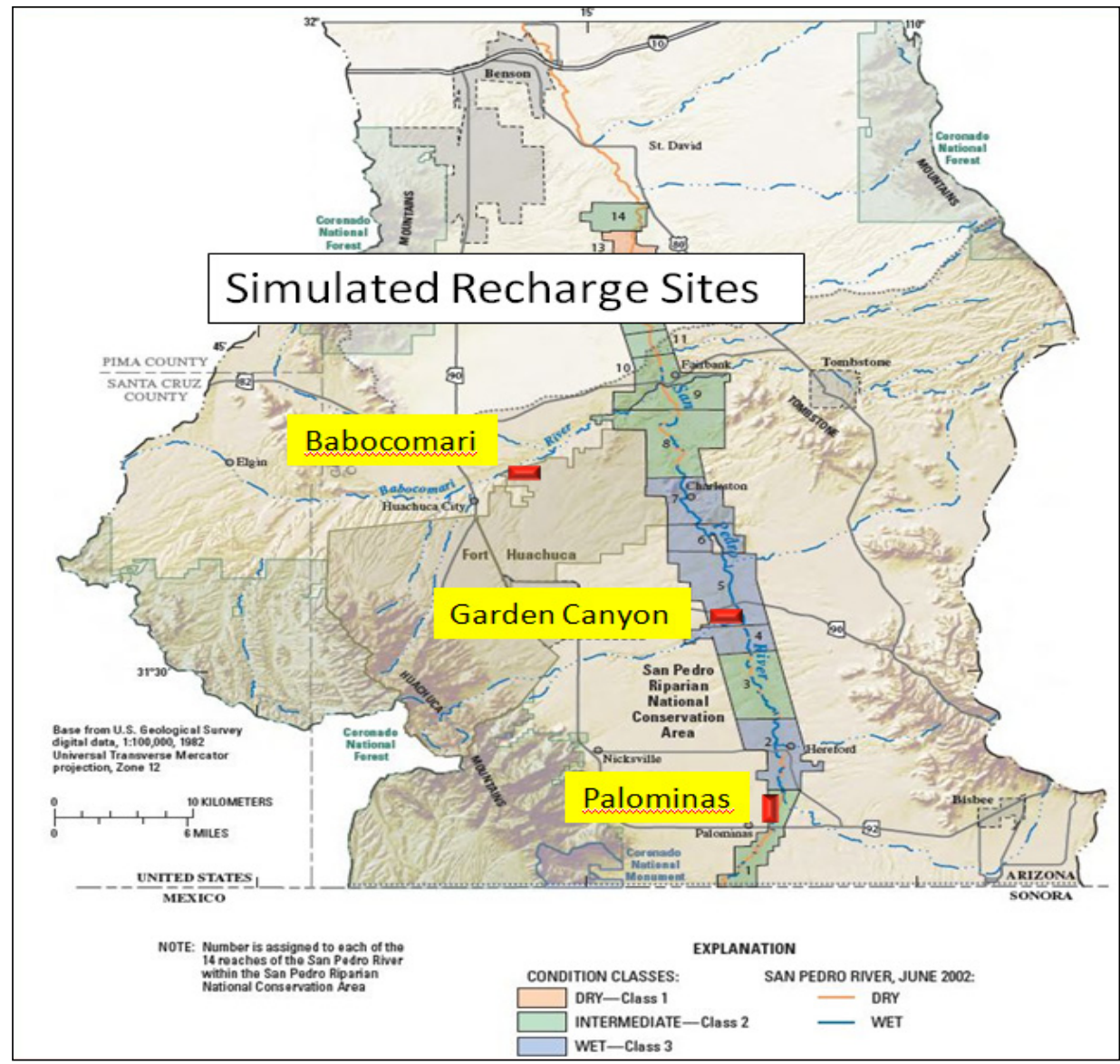

Figure 13. Simulated difference in baseflow (cu-m/d) in basin streams from 2003 conditions in: (a) 2030; (b) 2050; (c) 2070; and (d) 2111.

Simulated Difference in Baseflow from 2003 Conditions Baseline Model

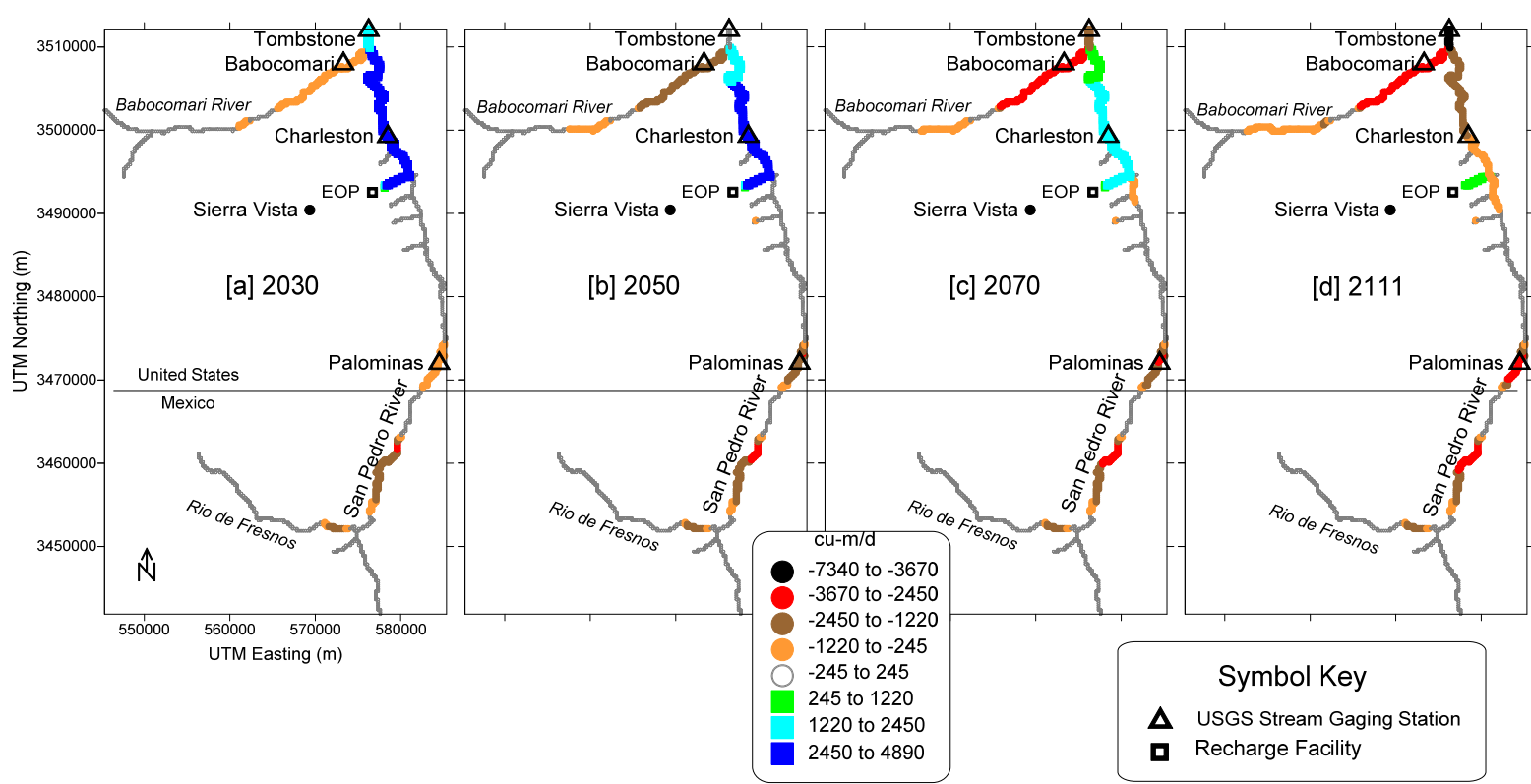




\subsubsection{Simulation Results}

Hydraulic conductivity, antecedent depth to groundwater, and projected aquifer storage depletion over time controlled the simulated baseflow response to recharge at each of the three trial sites. Since simulated recharge applied at each of the three trial sites was tailored to meet the anticipated baseflow deficit downstream, each site demanded a unique recharge distribution and exhibited a unique response to the simulated recharge. Figure 14 illustrates the recharge rates determined by trial and error as necessary to sustain simulated baseflows at or above 2003 levels in the groundwater model [3] through 2111. While each of the three test sites exhibited a unique response to the simulated recharge rates shown in Figure 14, the Babocomari site exhibited a much higher demand for recharge and a much more pronounced response in the underlying groundwater than the other two sites [58]. For the purpose of illustration, only the Babocomari test site recharge results will be discussed in detail here.

Figure 14. Simulated recharge rates for the Babocomari, Palominas, and Garden Canyon test sites.

Simulated Recharge Rates for Individual Test Sites

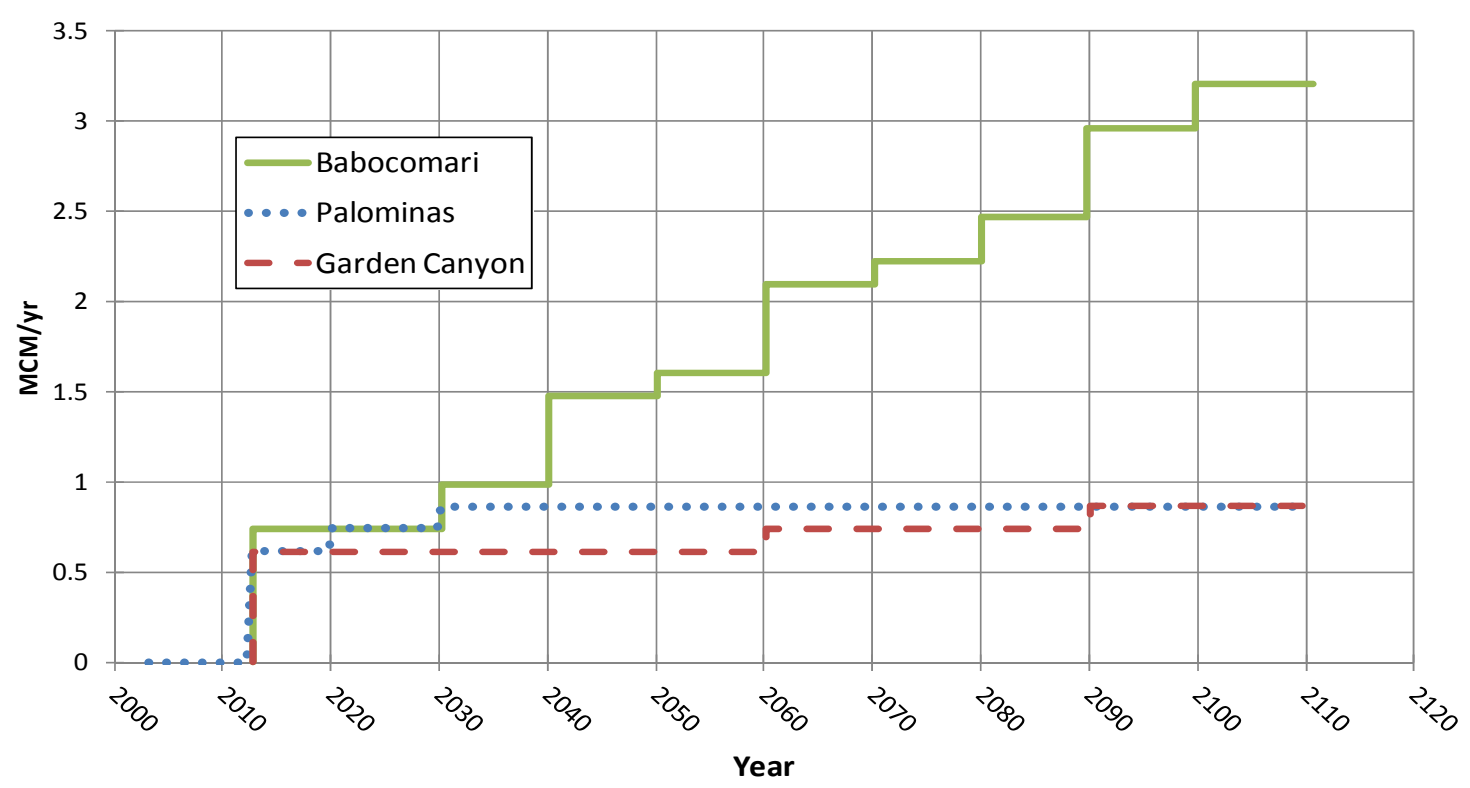

Figure 15 illustrates the groundwater response to recharge at the Babocomari site. The black line represents depth to groundwater (DTW) under the stream adjacent to the recharge site in the baseline model with no simulated recharge at the Babocomari site. The orange line shows DTW in response to a constant rate of $0.62 \mathrm{MCM} / \mathrm{yr}$. recharge, and the blue line shows DTW in the same location under the stream for the varying-recharge scenario illustrated by the green "Variable Recharge Rate" line. In the absence of any intervention (black DTW curve), simulated heads at this site are projected to drop by more than $10 \mathrm{~m}$ over the $21 \mathrm{st}$ century in response to pumping. However, these simulations suggest that incrementally increasing recharge from an initial rate of $0.74 \mathrm{MCM} / \mathrm{yr}$ in 2012 to $3.2 \mathrm{MCM} / \mathrm{yr}$ by 2100 would successfully maintain groundwater levels under the river at or slightly above the 2003 level.

The oscillation in the blue DTW curve reflects the fact that the simulated variable recharge increased groundwater levels under the river to a depth between the top of the evapotranspiration (ET) surface (1.5 $\mathrm{m}$ below top of aquifer) and the ET extinction depth at $6 \mathrm{~m}$ below the top of the aquifer. Thus, 
groundwater is more accessible to riparian vegetation in the varying-rate recharge scenario than in the baseline case, but baseflows still remain at or above 2003 levels in the area of the stream downstream where baseflow declines are projected under baseline conditions.

Figure 15. Simulated variable recharge rate at the Babocomari site and depth to water (DTW) under stream adjacent to the Babocomari recharge site from 2012 to 2111 for three scenarios: (a) no recharge; (b) $0.62 \mathrm{MCM}$ constant-rate recharge; and (c) variable-rate recharge scenarios [58]. Evapotranspiration (ET) zone occurs between 1.5 and $6 \mathrm{~m} \mathrm{[3].}$

\section{Simulated Depth to Groundwater Under Stream Near Babocomari Site and Simulated Variable Recharge Rate Applied, 2012-2111}

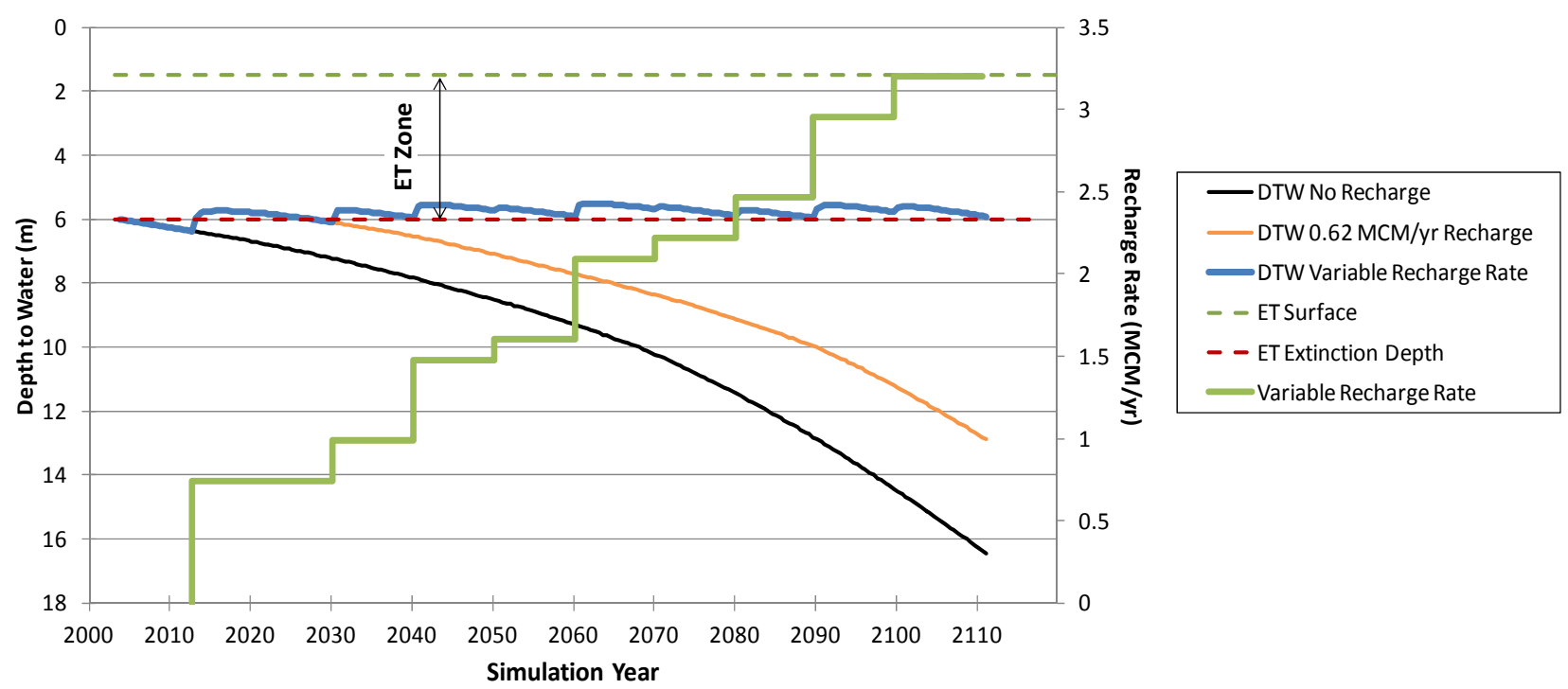

\subsubsection{Optimization of Recharge Rates}

Section 2.3.5 presented the results of simulated varying-rate recharge at each of three trial sites individually along the San Pedro and Babocomari Rivers. One additional simulation combining the three trial recharge sites was run in order to answer the question of whether hydrologic efficiencies might be gained with simultaneous recharge at all three sites [58]. Because the reach of the San Pedro affected by simulated recharge at the Garden Canyon site is downstream of both the Babocomari and Palominas sites, some reduction in the required recharge at the Garden Canyon site was achieved by combining all three trial recharge sites in a single simulation. Figure 16 illustrates the reduced recharge required at the Garden Canyon site to maintain simulated baseflows downstream of that site at 2003 levels when recharge is simulated at the Palominas and Babocomari trial sites concurrently.

Total recharge required to maintain simulated baseflows at 2003 levels downstream of each of the three test sites is shown in Figure 17. The blue curve shows the total recharge required when the three sites are simulated independently of each other, and the green curve shows the total recharge requirement when all three test sites are simulated concurrently. The difference between the curves illustrates the efficiency gained by combining the three recharge test sites. The maximum total recharge rate in the independent simulations is $4.93 \mathrm{MCM} / \mathrm{yr}$ (3.35 MCM/yr average over the 2012-2111 period), but that value drops to $4.63 \mathrm{MCM} / \mathrm{yr}(2.91 \mathrm{MCM} / \mathrm{yr}$ average) for the concurrent recharge simulations. The 
average recharge saved by operating all three sites concurrently is $0.45 \mathrm{MCM} / \mathrm{yr}$. Figure 18 shows the final simulated change in baseflow from 2003 conditions when recharge at the three test sites is optimized for concurrent simulation of the three sites.

Figure 16. Simulated variable recharge rates for the Babocomari, Palominas and Garden Canyon test sites. Simulating recharge at all three sites concurrently allowed a reduction in Garden Canyon recharge relative to the rates for the independent recharge simulations.

\section{Simulated Recharge Rates Optimized for Combined Test Sites}

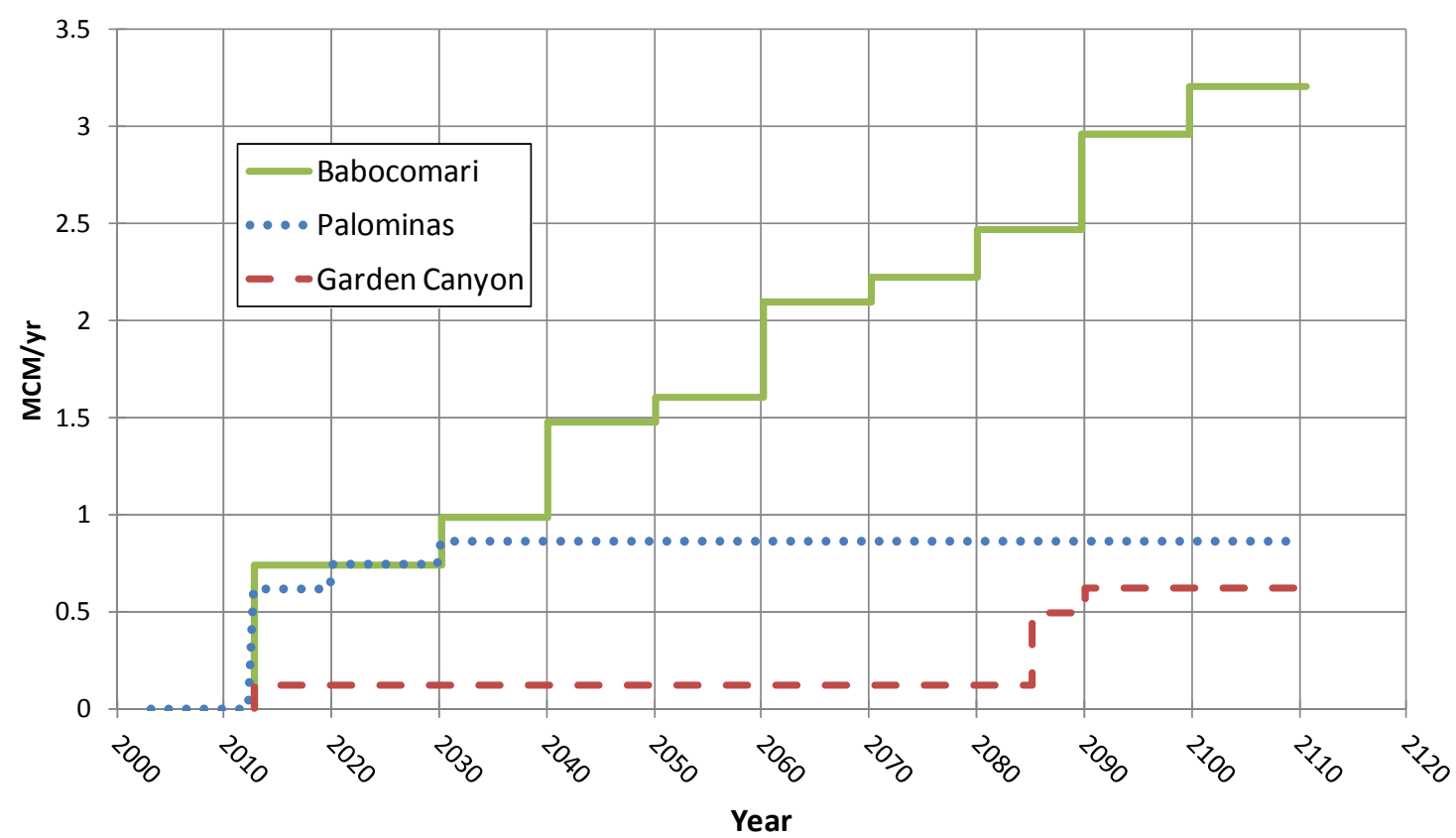

Figure 17. Total simulated recharge at the Babocomari, Palominas, and Garden Canyon test sites required to maintain baseflows downstream of each site at or above 2003 levels when recharge is simulated at each site independently and when all three sites are simulated concurrently.

Simulated Total Near-Stream Recharge at Three Sites Required to Sustain Baseflows at 2003 Levels

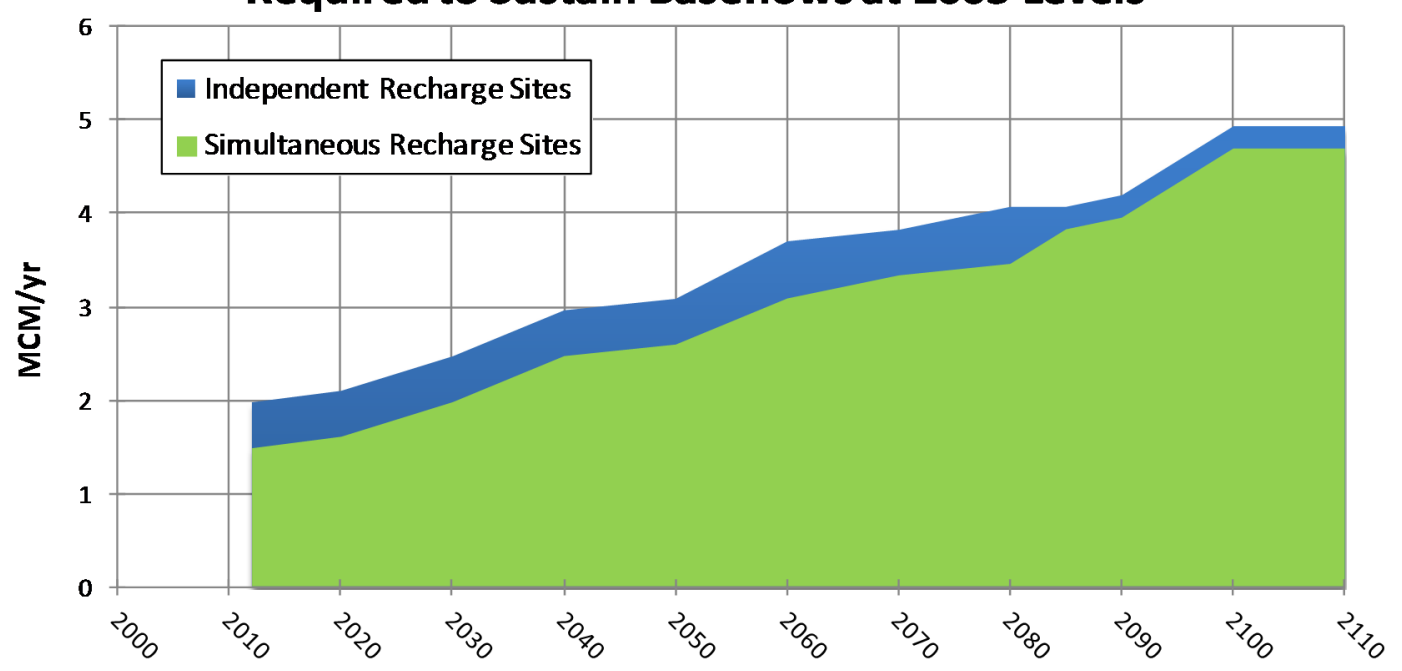


Figure 18. Simulated difference in March baseflow (cu-m/d) from 2003 conditions with optimized variable-rate recharge at three trial recharge sites in: (a) 2030; (b) 2050; (c) 2070; and (d) 2111.

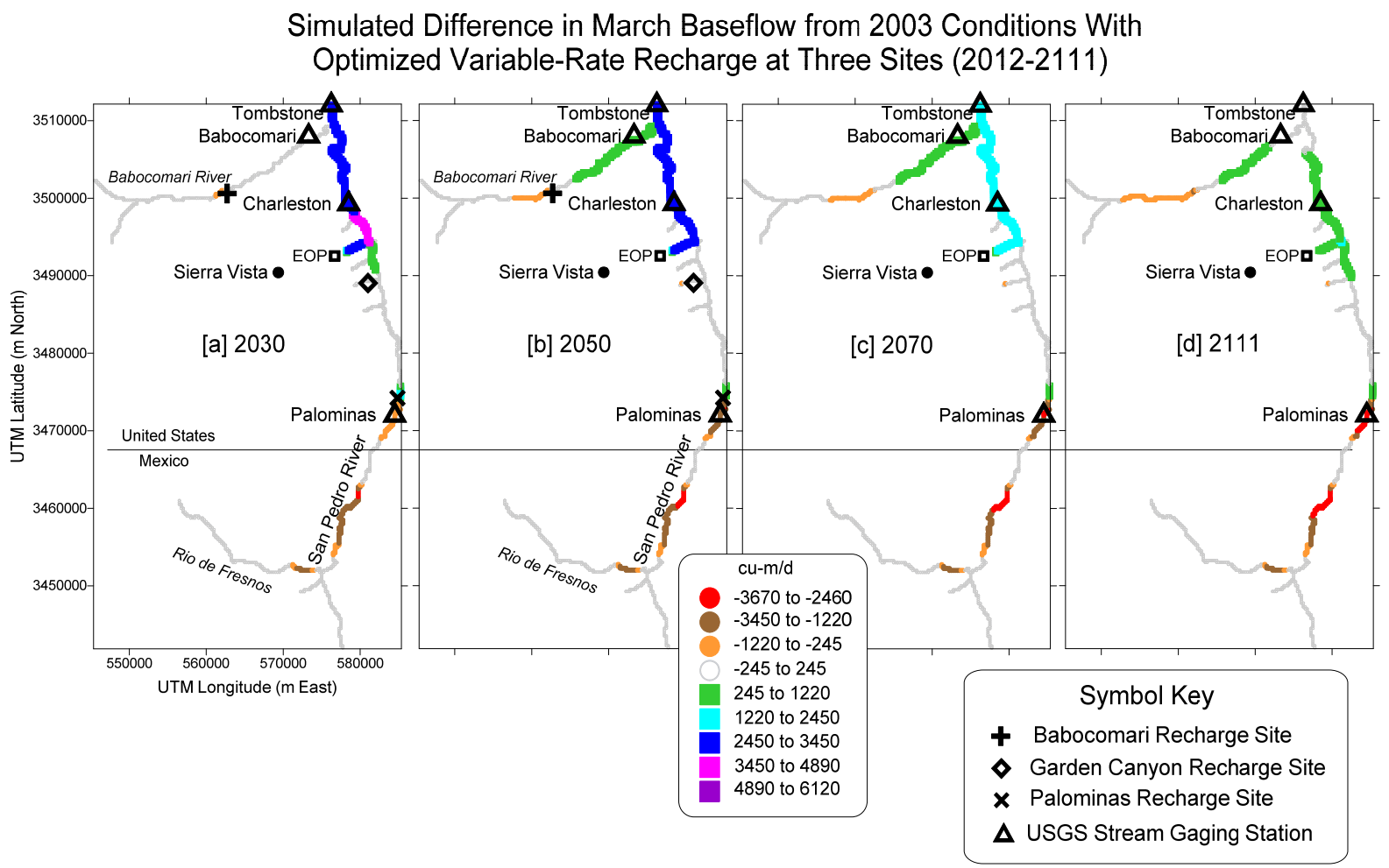

\subsubsection{Advantages/Disadvantages and Evolution of the Tool}

Any perceived bias in the construction of the model, or simple disagreements among stakeholders with the technical modeling approach, can be problematic in terms of how modeling results will be used, if at all. Engagement of stakeholders throughout the model development process is essential for it to be embraced as a useful tool for decision making among varied interests. In this case, the groundwater model [3] was developed in response to wide dissatisfaction with some precursor models of the subwatershed. Richter and others [1] describe the process by which stakeholders were involved in the development of the Pool and Dickinson model [3] and the evolution of trust in the model among technical water resources experts and politicians in the basin.

Several years of experience with the Pool and Dickinson model [3] in developing and communicating results of baseline projections helped pave the way for using it as a tool to evaluate the prospects of near-stream recharge. The model made experimenting with various recharge rates and tracking the resultant changes in baseflow a fairly quick and inexpensive undertaking. While we feel that these simulation efforts successfully conveyed the general concept and potential merits of near-stream recharge to the public and decision makers, significant criticism arose from our choice of an arbitrary initial recharge rate of $0.62 \mathrm{MCM} / \mathrm{yr}$ for the hypothetical recharge sites. We viewed the initial near-stream recharge simulations as an exploratory mission to determine how much water would be required to produce the desired effect on baseflows in the San Pedro River, irrespective of the potential feasibility of attaining that quantity of water or distributing it in the locations of interest. As our initial simulation results were presented to stakeholders, many of them questioned the value in simulating recharge with 
water that is not available and for which no plans to develop were pending. We saw the near-stream modeling process as a "proof-of-concept" effort, but others quickly made the leap to the real difficulties in securing water for recharge. Significant time and energy were expended in efforts to bridge this conceptual gap, and in hindsight, more early effort to clarify the purpose and strategy behind the simulations would have been helpful.

\subsubsection{Application of Recharge Simulations to Upper San Pedro Parcels}

The primary value in the groundwater modeling efforts undertaken for the three "test sites" described above was in proving the potential benefit of multiple recharge sites near the river. In recent years, the U.S. Army Compatible Use Buffer program, Cochise County, and The Nature Conservancy collaboratively acquired and set aside for conservation purposes four parcels on the west side of the San Pedro River totaling 2226 hectares within the subwatershed (Figure 5). Collectively, these properties make up the physical sites currently under consideration for development of a network of near-stream recharge projects. The groundwater modeling process detailed above for the three hypothetical "test sites" was employed to some extent in the preliminary planning process for parcels 1 and 3 in Figure 5. As projects move from the conceptual phase to the physical site investigation stage, use of the groundwater model is being adapted to suit the project planning needs for the individual sites. While development of a recharge project on parcel 1 was constrained by several factors (parcel size, flood-control objectives, location of high-permeability soils off site), the current planning process for parcel 3 is relatively unconstrained. Modifications to model structure to reflect observed field conditions and refinement of the model grid to allow for more detailed simulation of potential recharge are two of the anticipated outcomes of the next phase of investigation at parcel 3.

\section{Results and Discussion}

The suite of analytical tools discussed here is being used to inform key decisions necessary to balance groundwater use and maintain San Pedro River flows and associated riparian area ecological health. An extensive collection of hydrological studies and a robust, long-term monitoring program in the San Pedro basin have provided policy makers and stakeholders with important information about the complex relationships between groundwater condition, streamflow, and the ecological integrity of the riparian system within and near the SPRNCA. As a result, most of the stakeholders in the subwatershed understand that much of the San Pedro's riparian vegetation uses groundwater from the stream alluvium, and that this alluvial aquifer stores water from flood flows, receives groundwater from the regional aquifer, and contributes baseflow to the river during low-flow periods.

The groundwater model used in this study does not incorporate the complex interactions between flood-driven recharge of the shallow alluvium which influences baseflow to varying degrees from year to year, and pumping-induced depletions of the regional aquifer, which take decades to centuries to alter baseflow. While the model's authors made every effort to exclude storm-flow influences from the baseflow measurements they used in model calibration [3], it is virtually impossible to ensure that any given measured baseflow value represents only regional aquifer groundwater. The implication of this limitation is that the model may slightly overestimate the regional aquifer's contribution to baseflow, which would manifest as overestimated aquifer transmissivity and/or streambed conductance. That 
outcome, in turn, means that the model would also overestimate the simulated impact of pumping on baseflow until capture reaches its maximum (equilibrium) value. For the purpose of this study, which is to develop strategies for mitigating pumping-related impacts on baseflow, that response would be conservative and acceptable.

The Pool and Dickinson [3] model represents the culmination of years of study and is the best tool currently available for the study area. As discussed by Richter and others [1], using a groundwater model that is accepted by the vast majority of decision makers to perform predictive groundwater modeling has been essential for beginning to make management and project decisions from a common starting point. The modeling has demonstrated that within the next 100 years, two regional cones of depression will enlarge and likely change the nature of the hydrologic connection between the San Pedro River and the regional aquifer, reducing baseflow and impacting the dependent riparian system and thus wildlife populations.

Awareness and acceptance of an impending problem, however, is only the first step in finding a solution. The additional tools of the wet/dry maps and groundwater capture/recharge maps helped to focus management attention on finding both the most vulnerable areas of the system and the most beneficial locations for mitigation efforts. Analysis of wet/dry maps showing surface water presence during the driest time of year and areas with high year-to-year variation in wetted length may be the first physical evidence of changes in local groundwater conditions at the river. While wetted length is not solely controlled by groundwater conditions (it may also be affected by climate), different trends in various reaches of the river may help identify areas at higher risk of future ecological changes. Aligning these low-flow river reaches with the groundwater capture maps provided a rough indication of the rate that recharge in those areas of the aquifer might respond, expressing itself as baseflow in the San Pedro River. The capture maps also suggested the suitability of various locations for recharge that may communicate with the alluvial aquifer and/or the San Pedro River. On-site investigation of actual hydrogeologic conditions and suitability for recharge at a particular location is the first step toward refining a preliminary conceptual model derived from the tools described in this paper.

In the San Pedro basin, the use of these complementary approaches informed the purchase of the most hydrologically sensitive lands near or adjacent to SPRNCA (Figure 5) in order to both defer residential and/or agricultural development and provide the opportunity for near-stream recharge project development. The concept of a strategically located network of recharge projects near these river reaches evolved, in part, from the success of more than a decade of managed aquifer recharge at the City of Sierra Vista Environmental Operations Park in supporting both baseflow and replenishing the deep regional aquifer. We anticipate that recharging urban-enhanced runoff, storm water, and treated effluent near at-risk reaches shown would create groundwater mounds to sustain surface water flow and supplement alluvial groundwater levels during low-flow periods, effectively compensating for the otherwise deleterious impacts of encroaching cones of depression in the regional aquifer on baseflows for the next several decades or more.

\section{Conclusions}

The application of the study methods presented in this paper and the development of system-specific techniques appear to have great promise for protecting dry-land riparian systems from the impacts of 
groundwater extraction, surface water diversions, and the extremes of climate change for up to several decades. The ecological, cultural, and economic significance of the San Pedro River has made it one of the most well-studied and understood river systems in the world. The tremendous volume of data and hydrologic tools already developed for this specific system coupled with many years of collaborative partnerships that have matured with the science make the San Pedro basin a very unique policy environment. There is likely no other river system with an identical set of social, political, and ecological circumstances, but the hydrologic analysis tools described in this paper can be used anywhere. The strength of collaborative partnerships and knowledge of which tools they jointly support is key to building a common understanding of the history, goals, and resources at hand to make real progress.

\section{Acknowledgments}

The authors would like to acknowledge the Walton Family Foundation for its support in funding much of the science and policy development in the Upper San Pedro Basin in recent years. They would also like to express gratitude to the reviewers whose collective input substantially improved this paper.

\section{Author Contributions}

The text of this article was written by Laurel J. Lacher, Dale S. Turner, Bruce Gungle, and Brooke M. Bushman, with contributions by Holly E. Richter. Laurel Lacher conducted background research on capture and urban-enhanced runoff, and performed the simulations of near-stream recharge. Bruce Gungle compiled and synthesized water budget data for the Upper San Pedro Partnership and provided the literature review. Dale Turner compiled and synthesized wet/dry mapping data. Brooke Bushman provided coordination of the research efforts in her role as the Upper San Pedro Basin Program Coordinator for The Nature Conservancy. Holly Richter provided content review and helped shape the presentation of our findings.

\section{Conflicts of Interest}

The authors declare no conflict of interest.

\section{References}

1. Richter, H.E.; Gungle, B.; Turner, D.S.; Bushman, B.; Lacher, L.J. Development of a Shared Vision Toward Sustainability of Groundwater to Protect and Sustain Baseflows of the Upper San Pedro River, Arizona. Water 2014, 6, 2519-2538.

2. United States Congress. Arizona-Idaho Conservation Act of 1988, Public Law 100-696, Title I, 1988.

3. Pool, D.R.; Dickinson, J.E. Ground-Water Flow Model of the Sierra Vista Subwatershed and Sonoran Portions of the Upper San Pedro Basin, Southeastern Arizona, United States, and Northern Sonora, Mexico; U.S. Geological Survey: Reston, VA, USA, 2007; p. 47.

4. Cooperative Climatological Data Summaries for Arizona. Data for Coronado National Monument, Sierra Vista, and Tombstone stations. Available online: http://www.wrcc.dri.edu/summary/ Climsmaz.html (accessed on 13 June 2014). 
5. Thomas, B.E.; Pool, D.R. Trends in Streamflow of the San Pedro River, Southeastern Arizona, and Regional Trends in Precipitation and Streamflow in Southeastern Arizona and Southwestern New Mexico; U.S. Geological Survey Professional Paper 1712; U.S. Geological Survey: Reston, VA, USA, 2007; p. 79.

6. 2013-2050 Sub-county Population Projections. Available online: http://www.workforce.az.gov/ population-projections.aspx (accessed on 13 June 2014).

7. July 1, 2013 Population estimates for Arizona's counties, incorporated places and unincorporated balance of counties. Available online: http://www.workforce.az.gov/pubs/demography/July\%201_ 2013\%20PopulationEstimates_Final.pdf (accessed on 13 June 2014).

8. Carreira, R. Economic Impact of Fort Huachuca. Undated white paper. Center for Economic Research at Cochise College. Available online: http:/www.cochise.edu/cfiles/files/CER/ CER\%20Studies/Economic_Impact_of_Fort_Huachuca.pdf (accessed on 13 June 2014).

9. Skagen, S.K.; Melcher, C.P.; Howe, W.H.; Knopf, F.L. Comparative use of riparian corridors and oases by migrating birds in southeast Arizona. Conserv. Biol. 1998, 12, 896-909.

10. Stromberg, J.C.; Lite, S.J.; Dixon, M.; Rychener, T.; Makings, E. Relations between streamflow regime and riparian vegetation composition, structure, and diversity within the San Pedro Riparian National Conservation Area, Arizona. In Hydrologic Requirements of and Consumptive Ground-Water Use by Riparian Vegetation along the San Pedro River, Arizona; Leenhouts, J.M., Stromberg, J.C., Scott, R.L., Eds.; U.S. Geological Survey Scientific Investigations Report 2005-5163; U.S. Geological Survey: Reston, VA, USA, 2006; pp. 57-106.

11. Stromberg, J.C.; Bagsted, K.J.; Leenhouts, J.M.; Lite, S.J.; Making, E. Effects of stream flow intermittency on riparian vegetation of a semiarid region river (San Pedro River, Arizona). River Res. Appl. 2005, 21, 925-938.

12. Haynes, C.V., Jr. Curry Draw, Cochise County, Arizona: A late Quaternary stratigraphic record of Pleistocene extinction and paleo-Indian activities. In Geologic Diversity of Arizona and Its Margins: Excursions to Choice Areas; Arizona Bureau of Geology and Mineral Technology Special Paper 5; Davis, G.H., VandenHolder, E.M., Eds.; U.S. Department of the Interior: Phoenix, AZ, USA, 1987; pp. 23-28.

13. U.S. Bureau of Land Management. Tucson Field Office Paleontology Sites. Available online: http://www.blm.gov/az/st/en/prog/cultural.html (accessed on 15 June 2014).

14. Hereford, R. Entrenchment and Widening of the Upper San Pedro River, Arizona; Special Paper 282; Geological Society of America: Boulder, CO, USA, 1993; p. 46.

15. Arizona Department of Water Resources. Surface Water Adjudications. Available online: http://www.azwater.gov/AzDWR/SurfaceWater/Adjudications/ (accessed on 15 June 2014).

16. U.S. Department of Agriculture-Agricultural Research Service Experimental Watersheds. Available online: http://www.ars.usda.gov/Research/docs.htm?docid=10978\&page=2 (accessed on 15 June 2014).

17. Brown, S.G.; Davidson, E.S.; Kister, L.R.; Thomsen, B.W. Water Resources of Fort Huachuca Military Reservation, Southeastern Arizona; U.S. Geological Survey Water-Supply Paper 1819-D; U.S. Geological Survey: Reston, VA, USA, 1966; pp. D1-D57. 
18. Brown, S.G.; Aldridge, B.N. Streamflow Gains and Losses and Ground-Water Recharge in the San Pedro River Basin, Arizona; USGS Administrative Report; U.S. Geological Survey: Reston, VA, USA, 1973; p. 45.

19. Freethey, G.W. Hydrologic Analysis of the Upper San Pedro Basin from the Mexico-United States International Boundary to Fairbank, Arizona; U.S. Geological Survey Open-File Report 82-752; U.S. Geological Survey: Reston, VA, USA, 1982; p. 52.

20. Vionnet, L.B.; Maddock, T. Modeling of Ground-Water Flow and Surface Water/Groundwater Interactions in the San Pedro River Basin-Part I-Cananea, Mexico to Fairbank, Arizona; HWR Report No. 92-010; University of Arizona: Tucson, AZ, USA, 1992; p. 96.

21. Corell, S.W.; Putman, F.; Lovvik, D.; Corkhill, F. A Groundwater Flow Model of the Upper San Pedro Basin, Southeastern Arizona; Phoenix, Arizona Department of Water Resources Modeling Report No. 10; Arizona Department of Water Resources: Phoenix, AZ, USA, 1996; p. 85.

22. Goode, T.; Maddock, T., III. Simulation of Groundwater Conditions in the Upper San Pedro Basin for the Evaluation of Alternative Futures; HWR report No. 00-30; Department of Hydrology and Water Resources, University of Arizona: Tucson, AZ, USA, 2000.

23. Arizona Department of Water Resources. Hydrographic Survey Report (HSR) for the San Pedro River Watershed; Arizona Department of Water Resources: Phoenix, AZ, USA, 1990; p. 548.

24. Arizona Department of Water Resources. Upper San Pedro Basin Active Management Area Report, March 2005; Arizona Department of Water Resources: Phoenix, AZ, USA, 2005.

25. Pool, D.R.; Coes, A.L. Hydrogeologic Investigations of the Sierra Vista Sub-Watershed of the Upper San Pedro Basin, Cochise County, Southeast Arizona; USGS Water Resources Investigations Report 99-4197; U.S. Geological Survey: Tucson, AZ, USA, 1999; p. 41.

26. Cooperative water use management related to Fort Huachuca, Arizona, and Sierra Vista subwatershed. U.S. Public Law 108-136, Section 321, 2003.

27. Upper San Pedro Partnership. Water Management of the Regional Aquifer in the Sierra Vista Subwatershed, Arizona-2011 Report to Congress; U.S. Department of Interior: Washington, DC, USA, 2013; p. 16.

28. Coes, A.L.; Pool, D.R. Ephemeral-Channel and Basin-Floor Infiltration in the Sierra Vista Subwatershed, Arizona; U.S. Geological Survey Open-File Report 05-1023; U.S. Geological Survey: Reston, VA, USA, 2005; p. 67.

29. Gungle, B. Timing and Duration of Flow in Ephemeral Streams of the Sierra Vista Subwatershed of the Upper San Pedro Basin, Cochise County, Southeastern Arizona; U.S. Geological Survey Scientific Investigations Report 2005-5190; U.S. Geological Survey: Reston, VA, USA, 2006; p. 47.

30. Leenhouts, J.M.; Stromberg, J.C.; Scott, R.L. (Eds.) Hydrologic Requirements of and Consumptive Ground-Water Use by Riparian Vegetation Along the San Pedro River, Arizona; U.S. Geological Survey Scientific Investigations Report 2005-5163; U.S. Geological Survey: Reston, VA, USA, 2006; p. 154.

31. Leake, S.A.; Pool, D.R.; Leenhouts, J.M. Simulated Effects of Ground-Water Withdrawals and Artificial Recharge on Discharge to Streams, Springs, and Riparian Vegetation in the Sierra Vista Subwatershed of the Upper San Pedro Basin, Southeastern Arizona; U.S. Geological Survey Scientific Investigations Report 2008-5207; U.S. Geological Survey: Reston, VA, USA, 2008; p. 14. 
32. Kennedy, J.R.; Gungle, B. Quantity and Sources of Baseflow in the San Pedro River near Tombstone, Arizona; U.S. Geological Survey Scientific Investigations Report 2010-5200; U.S. Geological Survey: Reston, VA, USA, 2010; p. 43.

33. Lacher, L.J. Simulated Groundwater and Surface Water Conditions in the Upper San Pedro Basin, 1902-2105; Lacher hydrological Consulting: Tucson, AZ, USA, 2011.

34. Stantec. Cochise County Flood Control/Urban Runoff Recharge Plan; Stantec Consulting, Inc.: Tucson, AZ, USA, 2006.

35. GeoSystems Analysis, Inc. Hydrologic and Incidental Groundwater Recharge Study; Stantec Consulting, Inc.: Tucson, AZ, USA, 2006; p. 70.

36. U.S. Department of Agriculture-Agricultural Research Station. Automated Geospatial Watershed Assessment Tool, developed in cooperation with the U.S. Environmental Protection Agency. Available online: http://www.tucson.ars.ag.gov/agwa/index.php?option=com_content\&view= article\&id=5\&Itemid=26 (accessed on 14 June 2014).

37. GeoSystems Analysis, Inc. Storm Water Recharge Feasibility Analysis, Appendix B: AGWA/KINEROS Simulations for Coyote Wash Watershed; Report to Cochise County for Project SP-0011; GeoSystems Analysis, Inc.: Tucson, AZ, USA, 2004.

38. United States Bureau of Reclamation-Lower Colorado Region. Appraisal Report: Augmentation Alternatives for the Sierra Vista Subwatershed, Arizona; U.S. Department of Interior: Washington, DC, USA, 2007; p. 77.

39. United States Bureau of Reclamation. Grant No. 00-FC-32-0030 Between Bureau of Reclamation Phoenix Area Office and The City of Sierra Vista Pertaining to Construction of the Sierra Vista Water Reclamation Facility Effluent Recharge Demonstration Project, February 2000.

40. Brown and Caldwell. Sierra Vista Water Reclamation Facility Groundwater Modeling Study; Prepared for City of Sierra Vista; Brown and Caldwell: Sierra Vista, AZ, USA, 2009.

41. Turner, D.; Richter, H. Wet/Dry Mapping: Using Citizen Scientists to Monitor the Extent of Perennial Surface Flow in Dryland Regions. Environ. Manag. 2011, 47, 497-505.

42. Theis, C.V. The source of water derived from wells: Essential factors controlling the response of an aquifer to development. Civ. Eng. 1940, 10, 277-260.

43. Lohman, S.W.; Bennett, R.R.; Brown, R.H.; Cooper, H.H., Jr.; Drescher, W.J.; Ferris, J.G.; Johnson, A.I.; McGuiness, C.L.; Piper, A.M.; Rorabaugh, M.I.; et al. Definitions of Selected Ground-Water Terms-Revisions and Conceptual Refinements; U.S. Geological Survey Water-Supply Paper 1988; U.S. Geological Survey: Reston, VA, USA, 1972; p. 21.

44. Bredehoeft, J.D.; Papadopulos, S.S.; Cooper, H.H. Groundwater: The water budget myth. In Scientific Basis of Water-Resource Management, Studies in Geophysics; National Academy Press: Washington, DC, USA, 1981; pp. 51-57.

45. Brown, R.E. The Cone of Depression and the Area of Diversion around a Discharging Well in an Infinite Strip Aquifer Subject to Uniform Recharge; U.S. Geological Survey Water-Supply Paper 154SC; U.S. Geological Survey: Reston, VA, USA, 1963; pp. C69-C85.

46. Winter, T.C.; Harvey, J.W.; Franke, O.L.; Alley, W.M. Ground Water and Surface Water: A Single Resource; U.S. Geological Survey Circular 1139; U.S. Geological Survey: Reston, VA, USA, 1998; p. 15. 
47. Heath, R.C. Basic Groundwater Hydrology; U.S. Geological Survey Water Supply Paper 2220; U.S. Geological Survey: Reston, VA, USA, 1986; p. 86.

48. Lohman, S.W. Ground-Water Hydraulics; U.S. Geological Survey Professional Paper 708; U.S. Geological Survey: Reston, VA, USA, 1972; p. 70.

49. Leake, S.A.; Reeves, H.W.; Dickinson, J.E. A new capture fraction method to map how pumpage affects surface water flow. Groundwater 2010, 48, 690-700.

50. Barlow, P.M.; Leake, S.A. Streamflow Depletion by Wells-Understanding and Managing the Effects of Groundwater Pumping on Streamflow; U.S. Geological Survey Circular: 1376; U.S. Geological Survey: Reston, VA, USA, 2012; p. 95.

51. Leake, S.A.; Greer, W.; Watt, D.; Weghorst, P. Use of Superposition Models to Simulate Possible Depletion of Colorado River Water by Ground-Water Withdrawal; U.S. Geological Survey Scientific Investigations Report 2008-5189; U.S. Geological Survey: Reston, VA, USA, 2008; p. 25.

52. Harbaugh, A.W.; Banta, E.R.; Hill, M.C.; McDonald, M.G. MODFLOW-2000, the U.S. Geological Survey Modular Ground-Water Model-User Guide to Modularization Concepts and the Ground-Water Flow Process; U.S. Geological Survey Open-File Report 00-92; U.S. Geological Survey: Reston, VA, USA, 2000; p. 121.

53. Prudic, D.E. Documentation of a Computer Program to Simulate Stream-Aquifer Relations Using a Modular, Finite-Difference, Ground-Water Flow Model; U.S. Geological Survey Open-File Report 88-729; U.S. Geological Survey: Reston, VA, USA, 1989; p. 113.

54. Arizona Department of Commerce (AzDC) population projections for 2006, 2009, and 2010. Available online: http://www.azcommerce.com/EconInfo/Demographics/Population+Projections.htm (accessed on 30 October 2010).

55. TischlerBise. Infrastructure Improvements Plan and Development Fee Study; consulting report prepared for the City of Sierra Vista. TischlerBise: Bethesda, MD, USA, May 2009.

56. Upper San Pedro Partnership -Water Management of the Regional Aquifer in the Sierra Vista Subwatershed, Arizona-2004 Report to Congress; U.S. Department of Interior: Washington, DC, USA, 2005; p. 36.

57. Upper San Pedro Partnership-Water Management of the Regional Aquifer in the Sierra Vista Subwatershed, Arizona-2010 Report to Congress; U.S. Department of Interior: Washington, DC, USA, 2011; p. 20.

58. Lacher, L.J. Simulated Near-Stream Recharge at Three Sites in the Sierra Vista subbasin, Arizona; Lacher hydrological Consulting: Tucson, AZ, USA, 2012.

(C) 2014 by the authors; licensee MDPI, Basel, Switzerland. This article is an open access article distributed under the terms and conditions of the Creative Commons Attribution license (http://creativecommons.org/licenses/by/4.0/). 